\title{
NGNP Project Regulatory Gap Analysis for Modular HTGRs
}

September 2011

The INL is a

U.S. Department of Energy

National Laboratory

operated by

Battelle Energy Alliance

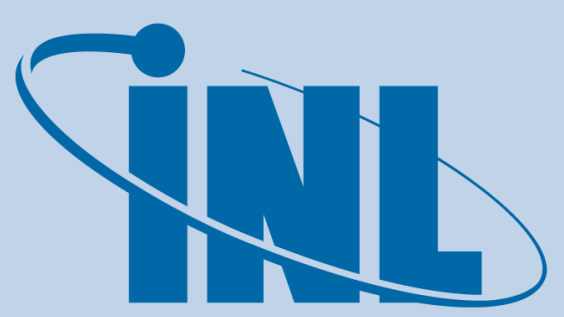

Idaho National Laboratory

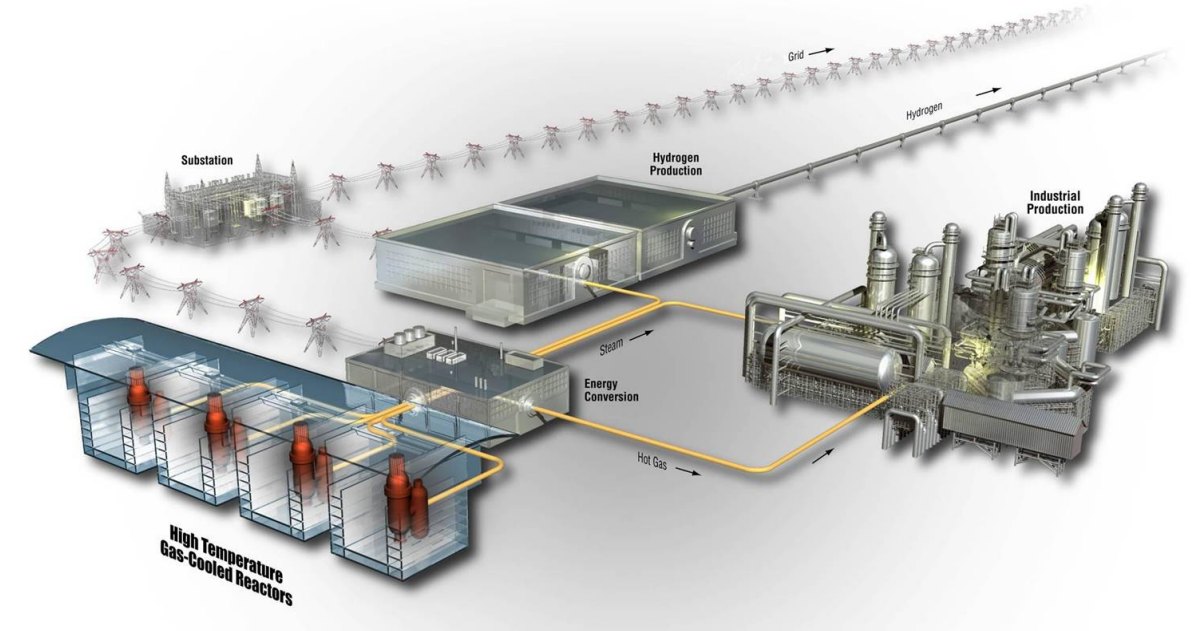




\section{DISCLAIMER}

This information was prepared as an account of work sponsored by an agency of the U.S. Government. Neither the U.S. Government nor any agency thereof, nor any of their employees, makes any warranty, expressed or implied, or assumes any legal liability or responsibility for the accuracy, completeness, or usefulness, of any information, apparatus, product, or process disclosed, or represents that its use would not infringe privately owned rights. References herein to any specific commercial product, process, or service by trade name, trade mark, manufacturer, or otherwise, does not necessarily constitute or imply its endorsement, recommendation, or favoring by the U.S. Government or any agency thereof. The views and opinions of authors expressed herein do not necessarily state or reflect those of the U.S. Government or any agency thereof. 


\section{NGNP Project Regulatory Gap Analysis for Modular HTGRs}

September 2011

Idaho National Laboratory

Next Generation Nuclear Plant Project

Idaho Falls, Idaho 83415

http://www.inl.gov

Prepared for the

U.S. Department of Energy

Office of Nuclear Energy

Under DOE Idaho Operations Office

Contract DE-AC07-05ID14517 



\section{Next Generation Nuclear Plant Project}

\section{NGNP Project Regulatory Gap Analysis for Modular HTGRs}

INL/EXT-11-23216

Revision 0

September 2011

Approved by:
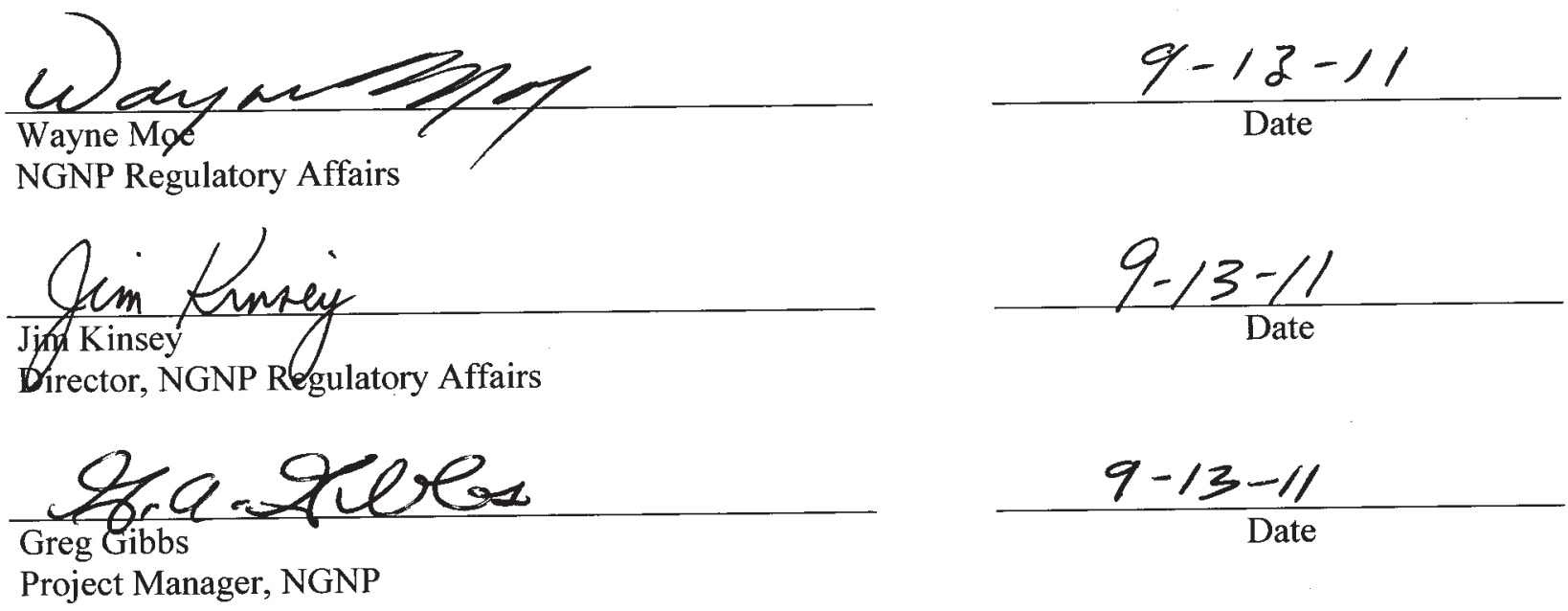



\section{SUMMARY}

The Next Generation Nuclear Plant (NGNP) Project Regulatory Gap Analysis (RGA) for High Temperature Gas-Cooled Reactors (HTGR) was conducted to evaluate existing regulatory requirements and guidance against the design characteristics specific to a generic modular HTGR. This final report presents results and identifies regulatory gaps concerning current Nuclear Regulatory Commission (NRC) licensing requirements that apply to the modular HTGR design concept. The report contains appendices that highlight important HTGR licensing issues that were identified during the RGA study. This information will be used to further efforts in reconciling HTGR-related gaps in the NRC licensing structure, which has to date largely focused on light water reactor technology.

The RGA was executed so that results can be generically applied to both pebble bed and prismatic block core modular HTGR designs. Notwithstanding HTGR design neutrality, the RGA utilized the Modular High Temperature GasCooled Reactor Preliminary Safety Information Document as the reference design basis. The MHTGR-PSID (a prismatic block design) was used because it contains a readily available description of a typical modular HTGR.

The RGA examined NRC regulatory and guidance positions according to the instructions contained in NGNP-LIC-ETR-PROC-0001, "Procedure for Performing the Regulatory Gap Analysis." The study assessed modular HTGR licensing activities within the contemporary NRC regulatory structure by applying existing requirements and guidance where applicable, necessary, and appropriate. The study noted limitations in the regulations and guidance that are important to HTGR licensing; it did not propose specific remedies or solutions for the identified licensing gaps.

The review focused on requirements and guidance considered relevant to development of an HTGR licensing framework and did not attempt to evaluate all NRC regulations that would be of interest to future HTGR license applicant(s). The regulatory statements and guidance positions that were evaluated were determined to be either as "Applicable," "Partially Applicable," or "Not Applicable" to a generic modular HTGR licensing action. Positions determined to be applicable in some degree were further analyzed concerning the type of applicability (regulation or guidance) and whether subsequent regulatory or design action might be appropriate.

Of the 3,611 items considered during the study, 1,022 were "Excluded" from further analysis because of their administrative nature or their being subject to determination by future license applicants. Of the 2,589 remaining items, 1,735 were designated as "Applicable" to the HTGR design, 463 as "Partially Applicable," and 391 were "Not Applicable." One hundred eight (108) of the analyzed positions were identified as needing further consideration and resolution in establishing a comprehensive HTGR licensing framework. Another 14 positions needed additional design information to support a determination of applicability.

Ninety three (93) of the 108 items recommended for further consideration were referenced in the NRC Standard Review Plan (SRP, NUREG-0800) or were contained in other guidance documents similar to NRC Regulatory Guides (RG), 
Divisions 1 and 4. These documents also contained most of the items that needed additional design information to support an applicability determination. Only 15 regulations were identified as needing adaptation in support of HTGR licensing action.

The analysis also identified a group of HTGR-specific topics that need further development within the existing NRC licensing structure to support future HTGR licensing actions. These are key issues concerning regulation and/or guidance that are considered important to establishing a comprehensive HTGR licensing framework and were recommended for further consideration and resolution on that basis. Some examples include HTGR fuel qualification, the use of high temperature materials, and the application of HTGR-compatible risk metrics. Efforts have already been initiated to approach a resolution to these particular items. Other issues, such as the use of helium as a reactor heat transfer fluid, may be furthered through future industry topical reports.

Overall, it was concluded that the majority of existing NRC regulations and guidance documents can be extended and adapted on a case-by-case basis to provide an effective licensing structure for modular HTGRs. However, areas do exist where additional developments in regulation and/or guidance may be warranted. 


\section{CONTENTS}

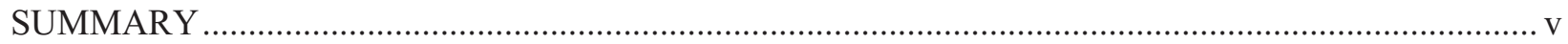

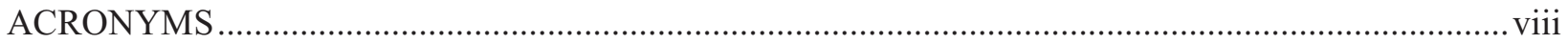

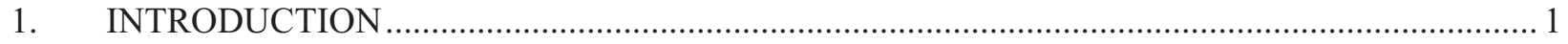

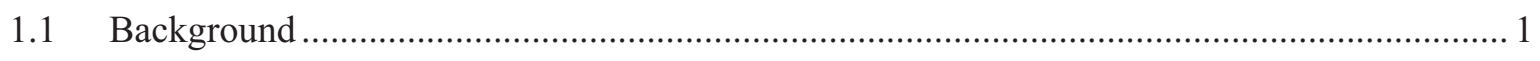

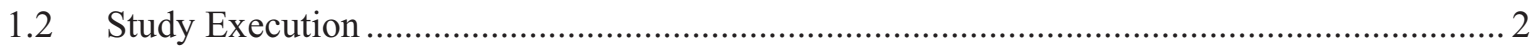

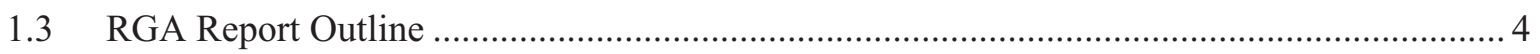

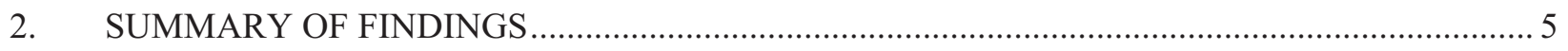

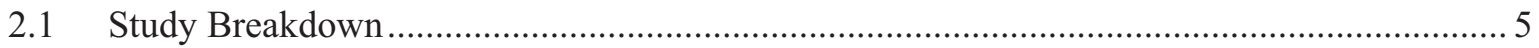

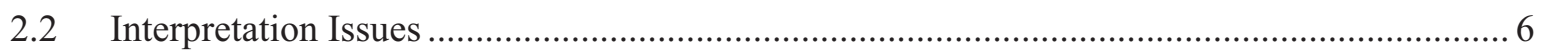

2.2.1 Modular High Temperature Gas-Cooled Reactor Preliminary Safety

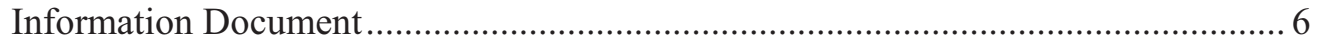

2.2.2 Functional Containment Performance........................................................... 7

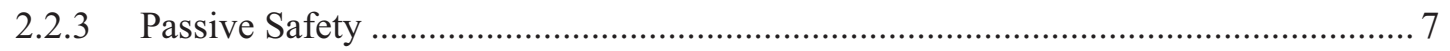

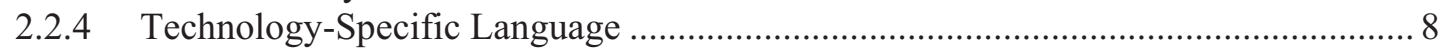

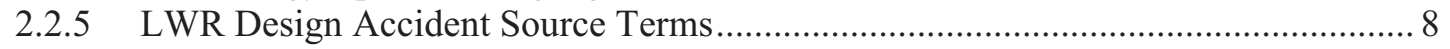

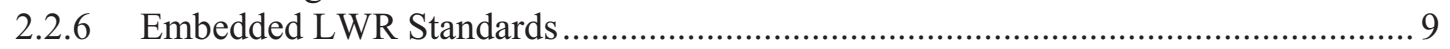

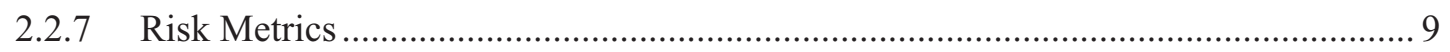

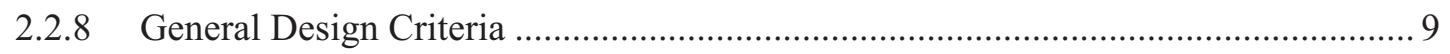

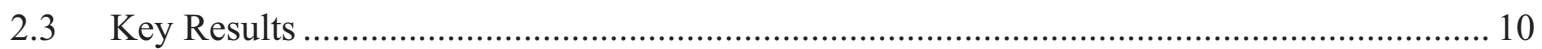

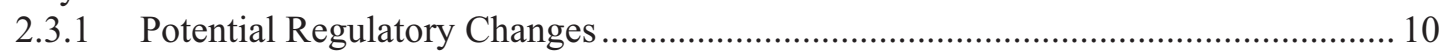

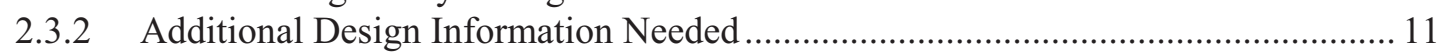

2.3.3 Key Regulatory Positions To Be Developed ..................................................... 12

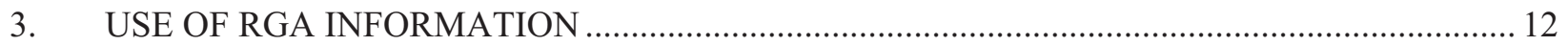

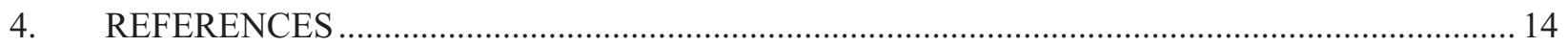

Appendix A Summary Table of Potential Regulatory Changes …...................................................... 16

Appendix B Summary Table of Additional Design Information Needed............................................... 28

Appendix C Table of Key Regulatory Guidance To Be Developed ...................................................... 31

\section{TABLES}

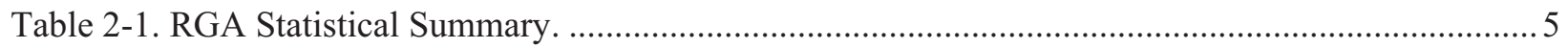

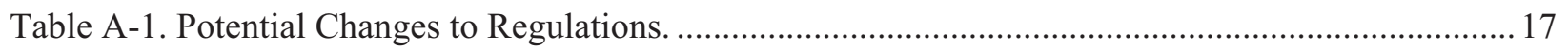

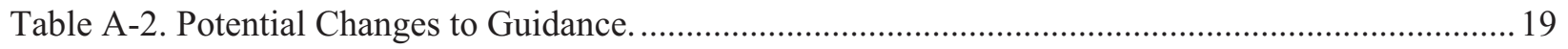

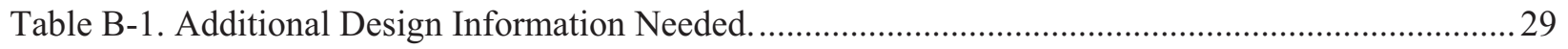

Table C-1. HTGR Regulatory Guidance to be Developed ...................................................................... 32 


\section{ACRONYMS}

ASME American Society of Mechanical Engineers

BTP Branch Technical Position

BWR boiling water reactor

CDF Core Damage Frequency

CFR Code of Federal Regulations

COL combined license

DOE United States Department of Energy

ECCS Emergency Core Cooling System

ER environmental report

ESF engineered safety feature

FPP fire protection program

GDC general design criteria

GSI generic safety issue

HTGR high temperature gas-cooled reactor

ISG Interim Staff Guidance

ISI in-service inspection

LERF Large Early Release Frequency

LOCA loss of coolant accident

LOFC loss of forced circulation

LWR light water reactor

MHTGR Modular High Temperature Gas-Cooled Reactor

NGNP Next Generation Nuclear Plant

NRC Nuclear Regulatory Commission

NUREG Nuclear Regulatory, NRC Staff Report

O\&M operation and maintenance

PRA probabilistic risk assessment

PSID Preliminary Safety Information Document

PWR pressurized water reactor

RG Regulatory Guide

RGA Regulatory Gap Analysis

SECY Secretary, Letter to the Secretary of the NRC

SRP Standard Review Plan

SSC structure, system and component 
TID Technical Information Document

TMI Three Mile Island

TRISO tristructural isotropic 


\section{NGNP Project Regulatory Gap Analysis for Modular HTGRs}

\section{INTRODUCTION}

The Next Generation Nuclear Plant (NGNP) Project Regulatory Gap Analysis (RGA) for high temperature gas-cooled reactors (HTGRs) was conducted to evaluate existing regulatory requirements and guidance against the specific design characteristics of a generic modular HTGR. The NGNP modular HTGR RGA study was completed in 2011. This report summarizes conclusions of that study and identifies certain "gaps" found in U.S. Nuclear Regulatory Commission (NRC) licensing requirements as they pertain to the HTGR design concept.

\subsection{Background}

Idaho National Laboratory manages the NGNP Project for the U.S. Department of Energy (DOE). The project was created to facilitate commercial deployment of modular HTGR plants that offer increased levels of inherent and passive safety. The underlying technologies of a HTGR are somewhat unique and differ from those found in traditional light water reactors (LWRs). Although there have been experiences in the past with non-LWR power plants, LWRs currently comprise the commercial nuclear power production base within the United States. Consequently, many (but not all) existing NRC regulations and related guidance are oriented towards LWR technology.

Existing NRC regulations and guidance may not adequately account for the distinctive features that must be considered when licensing HTGR technology. Modular HTGRs rely on a number of inherent characteristics and passive safety features to achieve safety objectives rather than employ the accident mitigation measures common for LWRs. HTGRs rely on the phenomena of its coated fuel particles, graphite moderator, helium coolant, and the passive heat removal capability of a low-power-density core within a steel reactor vessel to assure sufficient residual core heat removal.

Modular HTGRs employ five barriers against radionuclide release to the environment: fuel particle kernels, tristructural isotropic (TRISO) coated fuel particles (silicon carbide and pyrocarbon coatings), reactor core graphite and carbonaceous materials, a helium pressure boundary, and the reactor building. Together, these barriers establish a "functional containment" safety system. The effectiveness of these barriers in containing radionuclides depends on a number of factors, including the chemistry and half-life of the radionuclide, service conditions, and irradiation effects. The effectiveness of these release barriers is also event specific.

Modular HTGRs depart from LWR designs by employing graphite to maintain core geometry. Unlike LWR fuel cladding, graphite can withstand higher temperatures than the fuel itself without incurring structural damage. Furthermore, the massive graphite structures in the reactor core provide an extremely large heat capacity that, when coupled with the low power density of the core, results in very slow and predictable temperature transients. The mean free path of neutrons in graphite also provides a neutronically stable core that contributes to a very large negative temperature coefficient.

Helium rather than water is the heat transfer fluid for the HTGR primary loop. Helium is chemically inert and neutronically transparent, meaning it will not aggravate an accident by participating in any chemical or nuclear reaction. Helium will not change phase in the reactor, thus eliminating two-phased flow within the reactor circuit. It also minimizes primary system corrosion and greatly reduces buildup of radioactive byproducts. 
Modular HTGRs are designed to passively remove residual and decay heat from the core regardless of whether helium coolant is present. This is possible because of the large thermal margins, low power density, and graphite core configuration. The concrete walls surrounding the reactor vessel are covered by panels that remove heat radiating from the metal reactor vessel. These panels can be either air- or watercooled and are a key part of the reactor cavity cooling system.

Because of these and other features that differ significantly from LWR designs, a key task in establishing a modular HTGR licensing framework is to identify areas where existing requirements and guidance must be reconciled to accommodate HTGR design, operation, maintenance, testing, and inspection. The technology-oriented regulatory analysis described in this report was needed to identify gaps that might exist within NRC regulations and related guidance documents. This information can then be used to formulate subsequent courses of related licensing action.

\subsection{Study Execution}

The NGNP RGA effort focused on examining the licensing structure for nuclear reactors as established by the NRC and prescribed in Title 10 of the Code of Federal Regulations (CFR). The evaluation considered regulations and related guidance documents in effect as of June 1, 2010. It did not attempt to resolve the gaps in NRC regulation, guidance, or HTGR design identified during the analysis. Resolutions to such issues are expected to occur by way of NGNP Project interactions with the NRC through licensing white paper submittals, development of a HTGR combined license (COL) application Format and Content Guide, and various submittals by future COL applicants.

An initial screening was undertaken to identify those NRC regulations considered generally applicable to all technologies and not needing detailed evaluation for HTGR licensing such as 10 CFR Parts 2, 21, 26, 72, 74, and 95. These regulations were not included in the RGA evaluation. The RGA focused on those regulations and guidance documents relevant to development of a HTGR COL application Format and Content Guide that would be expected to resemble NRC Regulatory Guide (RG) 1.206, "Combined License Applications for Nuclear Power Plants, (LWR Edition).",

A team of nuclear power plant design engineers and regulatory analysts knowledgeable in HTGR design and experienced in NRC power reactor licensing performed the RGA study according to the scope provided by the "Procedure for Performing the Regulatory Gap Analysis."2 The procedure defined parameters for document review and specified the principal bodies of NRC regulation and guidance to be examined. These were:

- 10 CFR Part 20, Standards for Protection Against Radiation

- 10 CFR Part 50, Domestic Licensing of Production and Utilization Facilities (including the General Design Criteria, Appendix A)

- 10 CFR Part 51, Environmental Protection Regulations for Domestic Licensing and Related Regulatory Functions

- 10 CFR Part 52, Licenses, Certifications, and Approvals for Nuclear Power Plants

- 10 CFR Part 55, Operators' Licenses

- 10 CFR Part 70, Domestic Licensing of Special Nuclear Material

- 10 CFR Part 73, Physical Protection of Plants and Materials

- 10 CFR Part 100, Reactor Site Criteria

- 10 CFR Part 140, Financial Protection Requirements and Indemnity Agreements 
- 10 CFR Part 961, Standard Contract for Disposal of Spent Nuclear Fuel and/or High-Level Radioactive Waste

- $\quad$ NRC Regulatory Guide (Division 1), Power Reactors

- $\quad$ NRC Regulatory Guide (Division 4), Environmental and Siting

- NRC Regulatory Guide (Division 5), Materials and Plant Protection

- NUREG-0800, Safety Analysis Report Standard Review Plan (SRP)

- NUREG-1555, Environmental Report Standard Review Plan

- $\quad$ NRC Interim Staff Guidance (ISG), Generic Letters and SECY (Letter to the Secretary of the NRC) documents

- $\quad$ NUREG-0737, Three Mile Island (TMI) Requirements

- NUREG-0933, Unresolved and Generic Safety Issues (GSI)

The procedure provided instructions for executing the RGA study. Analysts and reviewers were briefed in the different HTGR technologies and trained to the procedure prior to initiating work. Additional briefings were held as needed to ensure decisional consistency. Supplemental work-level guidance was developed as necessary to enhance uniformity in applicability determinations.

Determinations included whether current regulations and associated regulatory guidance could be reasonably adapted to HTGR licensing actions as written. Certain items identified in the procedure, such as the regulations on violations and penalties of the Atomic Energy Act of 1954 that appear in 10 CFR $\S 20.2401$ and $\$ 20.2402$, respectively, were excluded from review because they were largely administrative in nature and would generally be expected to apply to HTGRs. Other items were excluded because they were subject to future determinations by COL applicant(s).

Of the regulations and guidance positions evaluated, the procedure provided one of three possible outcomes for an applicability determination:

Applicable. The regulation or regulatory guidance position specified a condition that is relevant and applicable to the modular HTGR design case. No modification to existing language is necessary for it to be applied in a HTGR licensing action.

However, if the language used in the regulation or guidance was not fully applicable to HTGRs, then the item could be designated as either Partially Applicable or Not Applicable:

Partially Applicable. The underlying principle or purpose of the requirement or guidance is applicable to the HTGR design but the statement cannot be applied as written, or some portion(s) of the requirement or guidance are applicable to the HTGR design while other portion(s) are clearly not applicable,

Not Applicable. A regulation or regulatory guidance position contains specific criteria with no equivalence or relevance to the HTGR design or its licensing basis.

Positions determined to apply in some degree were further evaluated concerning the type of applicability (i.e., formal regulatory requirement or guidance that can be employed to meet a regulatory requirement) and whether subsequent regulatory or design actions might be warranted in order to establish a path for adapting the item to HTGR licensing. 


\subsection{RGA Report Outline}

This report summarily identifies issues that need to be addressed as a part of establishing a NRC licensing framework for HTGRs. The report is structured to provide the following information:

- Section 1 provides background on the RGA study, its purpose, intent, and implementation.

- Section 2 presents a statistical summary of analyzed items. Some of the interpretational challenges relevant to the analysis are also discussed. Certain common "themes" of regulatory gaps are noted that should be considered during future related regulatory actions. Observations are made concerning design information needed to support specific determinations of applicability. Lastly, topics are identified that are not adequately addressed within the current NRC reactor licensing structure for HTGRs.

- Section 3 identifies how the RGA will be used to support development of the HTGR licensing framework and notes some limitations to the use of RGA results.

- Section 4 provides references cited in this report.

A summary of the RGA results are contained in the appendices:

- Appendix A contains a "Summary Table of Potential Regulatory Changes." Table A-1 identifies 15 existing regulations considered essential to HTGR licensing that might require revision or reinterpretation prior to their use in a HTGR licensing action. Table A-2 lists 93 related guidance positions that are not necessarily prerequisite to a HTGR licensing action but do merit further consideration in order to establish a more complete HTGR licensing framework.

- Appendix B lists 14 regulatory and guidance positions where licensing applicability could not be ascertained because of insufficient HTGR design information. This "Summary Table of Additional Design Information Needed" identifies issues that may or may not be applicable to a particular HTGR licensing action, depending upon the specific details of the final design.

- Appendix C identifies a group of topics for which new or revised regulatory guidance may be required to address the generic HTGR design and safety basis. These topics are not sufficiently addressed by any reviewed regulatory statement or guidance position but are still considered important in establishing a comprehensive HTGR licensing framework. 


\section{SUMMARY OF FINDINGS}

\subsection{Study Breakdown}

Table 2.1 presents a tabulation concerning the applicability of examined regulatory and guidance positions. It offers an approximation on the extent of applicability current NRC regulations and guidance documents have with respect to prospective HTGR licensing actions.

Table 2-1. RGA Statistical Summary.

\begin{tabular}{|c|c|c|c|c|c|c|c|c|}
\hline & $\begin{array}{l}\text { Total } \\
\text { Items }\end{array}$ & Excluded & $\begin{array}{c}\text { Items } \\
\text { Reviewed }\end{array}$ & Applicable & $\begin{array}{c}\text { Partially } \\
\text { Applicable }\end{array}$ & $\begin{array}{c}\text { Not } \\
\text { Applicable }\end{array}$ & $\begin{array}{c}\text { Reg } \\
\text { Needed }\end{array}$ & $\begin{array}{c}\text { Design } \\
\text { Info }\end{array}$ \\
\hline 10 CFR Part 20 & 78 & 15 & 63 & 63 & 0 & 0 & 0 & 0 \\
\hline 10 CFR Part 50 & 183 & 51 & 132 & 77 & 40 & 15 & 11 & 1 \\
\hline $\begin{array}{l}10 \text { CFR Part 50, } \\
\text { App. A (GDCs) }\end{array}$ & 67 & 0 & 67 & 34 & 21 & 12 & 0 & 0 \\
\hline 10 CFR Part 51 & 113 & 70 & 43 & 39 & 3 & 1 & 3 & 0 \\
\hline 10 CFR Part 52 & 170 & 100 & 70 & 64 & 2 & 4 & 0 & 0 \\
\hline 10 CFR Part 55 & 36 & 31 & 5 & 4 & 1 & 0 & 1 & 0 \\
\hline 10 CFR Part 70 & 60 & 60 & 0 & 0 & 0 & 0 & 0 & 0 \\
\hline 10 CFR Part 73 & 73 & 46 & 27 & 24 & 2 & 1 & 0 & 0 \\
\hline 10 CFR Part 100 & 44 & 6 & 38 & 30 & 0 & 8 & 0 & 0 \\
\hline 10 CFR Part 140 & 59 & 30 & 29 & 29 & 0 & 0 & 0 & 0 \\
\hline 10 CFR Part 961 & 6 & 2 & 4 & 3 & 1 & 0 & 0 & 0 \\
\hline $\begin{array}{l}\text { NRC Regulatory } \\
\text { Guides, Div } 1\end{array}$ & 390 & 39 & 351 & 233 & 78 & 40 & 29 & 7 \\
\hline $\begin{array}{l}\text { NRC Regulatory } \\
\text { Guides, Div } 4\end{array}$ & 61 & 14 & 47 & 34 & 13 & 0 & 12 & 1 \\
\hline $\begin{array}{l}\text { NRC Regulatory } \\
\text { Guides, Div } 5\end{array}$ & 89 & 66 & 23 & 25 & 0 & 0 & 0 & 0 \\
\hline NUREG-0800 (SRP) & 1458 & 11 & 1447 & 873 & 281 & 293 & 41 & 3 \\
\hline \multicolumn{9}{|c|}{ Breakdown of NUREG-0800 (Standard Review Plan, SRP) by chapter } \\
\hline SRP Chap $1 \& 2$ & 170 & 0 & 170 & 164 & 6 & 0 & 5 & 0 \\
\hline SRP Chap 3 & 191 & 0 & 191 & 163 & 4 & 24 & 2 & 0 \\
\hline SRP Chap 4 & 45 & 0 & 45 & 19 & 23 & 3 & 0 & 0 \\
\hline SRP Chap 5 & 143 & 1 & 142 & 49 & 22 & 71 & 1 & 0 \\
\hline SRP Chap 6 & 156 & 1 & 155 & 17 & 69 & 69 & 17 & 1 \\
\hline SRP Chap 7 & 126 & 2 & 124 & 110 & 0 & 14 & 0 & 0 \\
\hline SRP Chap 8 & 64 & 0 & 64 & 38 & 13 & 13 & 2 & 0 \\
\hline SRP Chap 9 & 147 & 1 & 146 & 65 & 46 & 35 & 0 & 2 \\
\hline SRP Chap 10 & 55 & 0 & 55 & 23 & 9 & 23 & 0 & 0 \\
\hline SRP Chap 11 & 54 & 0 & 54 & 46 & 8 & 0 & 6 & 0 \\
\hline SRP Chap 12 & 22 & 0 & 22 & 15 & 3 & 4 & 0 & 0 \\
\hline SRP Chap 13 & 73 & 0 & 73 & 48 & 21 & 4 & 4 & 0 \\
\hline SRP Chap 14 & 64 & 4 & 60 & 54 & 5 & 1 & 0 & 0 \\
\hline SRP Chap 15 & 110 & 2 & 108 & 37 & 45 & 26 & 3 & 0 \\
\hline SRP Chap $16 \& 17$ & 14 & 0 & 14 & 9 & 1 & 4 & 1 & 0 \\
\hline
\end{tabular}




\begin{tabular}{|c|c|c|c|c|c|c|c|c|}
\hline & $\begin{array}{l}\text { Total } \\
\text { Items }\end{array}$ & Excluded & $\begin{array}{c}\text { Items } \\
\text { Reviewed }\end{array}$ & Applicable & $\begin{array}{c}\text { Partially } \\
\text { Applicable }\end{array}$ & $\begin{array}{c}\text { Not } \\
\text { Applicable }\end{array}$ & $\begin{array}{c}\text { Reg } \\
\text { Needed }\end{array}$ & $\begin{array}{l}\text { Design } \\
\text { Info }\end{array}$ \\
\hline SRP Chap 18 & 3 & 0 & 3 & 3 & 0 & 0 & 0 & 0 \\
\hline SRP Chap 19 & 21 & 0 & 21 & 13 & 6 & 2 & 0 & 0 \\
\hline $\begin{array}{l}\text { NUREG-1555 } \\
\text { Environmental SRP }\end{array}$ & 150 & 15 & 135 & 121 & 9 & 5 & 4 & 0 \\
\hline $\begin{array}{l}\text { NRC Interim Staff } \\
\text { Guidance (ISG) }\end{array}$ & 30 & 9 & 21 & 13 & 7 & 1 & 5 & 0 \\
\hline $\begin{array}{l}\text { Generic Letters and } \\
\text { SECY Documents }\end{array}$ & 65 & 8 & 57 & 53 & 0 & 4 & 0 & 0 \\
\hline $\begin{array}{l}\text { NUREG-0737, Three } \\
\text { Mile Island Req'ts }\end{array}$ & 49 & 22 & 27 & 16 & 5 & 6 & 2 & 2 \\
\hline $\begin{array}{l}\text { NUREG-0933, } \\
\text { Unresolved and } \\
\text { Generic Safety Issues }\end{array}$ & 430 & 427 & 3 & 2 & 0 & 1 & 0 & 0 \\
\hline Totals & 3611 & 1022 & 2589 & 1735 & 463 & 391 & 108 & 14 \\
\hline$\%$ of Analyzed & & & $100 \%$ & $67 \%$ & $18 \%$ & $15 \%$ & & \\
\hline Notes: & & & & & & & & \\
\hline
\end{tabular}

The RGA study considered 3,611 separate regulatory items, 1,022 of which were "Excluded" from analysis because of their administrative nature or their being subject to future determination by an HTGR license applicant. Of the 2,589 nonexcluded items, 1,735 were determined to be "Applicable," 463 "Partially Applicable," and 391 "Not Applicable" to HTGR licensing. Of those positions determined partially applicable, 108 were noted as possibly requiring additional consideration. Fifteen of the 108 items recommended for additional consideration are regulations; the remainder is associated with the NRC SRP (NUREG-0800) or other guidance documents such as NRC RGs.

Fourteen of the analyzed regulatory positions needed additional design information to make a definitive determination about applicability. Only one regulation needed more design information to support a determination. The SRP and RGs contained the majority of items where additional design information is needed before reaching an applicability conclusion.

\subsection{Interpretation Issues}

Many interpretation challenges arose during the process of making individual RGA applicability determinations. Issues regarding the most appropriate understanding of regulatory wording and underlying intentions cut across a number of reviewed items. The following discussion provides insight into some of these challenges and conclusions.

\subsubsection{Modular High Temperature Gas-Cooled Reactor Preliminary Safety Information Document}

The principal design reference document for the RGA study was the "Preliminary Safety Information Document for the Standard MHTGR."3 The Modular High Temperature Gas-Cooled Reactor (MHTGR) Preliminary Safety Information Document (PSID) described a DOE-sponsored prismatic-block reactor core design that underwent preapplication review by the NRC in the 1980s and early 1990s. This review was documented in a NRC Safety Evaluation Report. ${ }^{4,5}$ The MHTGR-PSID contains the most comprehensive source of modular HTGR design information currently available in the public domain. For 
that reason, the MGTGR-PSID was employed as the RGA reference design. This reference material was supplemented by more recent design and licensing insights related to a pebble bed design certification effort from 2005, so that the analysis was representative of both pebble bed and prismatic block modular design types.

\subsubsection{Functional Containment Performance}

The HTGR concept of functional containment is a unique issue that caused many regulatory and guidance positions to be designated as "Partially Applicable" with "Further Guidance Required." This is largely attributed to the importance that a low leakage containment structure plays in LWR designs and the large number of regulatory positions that address LWR containment in very specific ways.

LWR containment generally infers the presence of an essentially leak tight "containment building," i.e., a structure that houses the reactor. Such a building is a principal barrier against fission product release and is treated in regulation as a safety class pressure retaining system. Key requirements associated with LWR-type containment include robust electrical penetration assemblies, containment isolation valves, blast resistant marine-style hatches, and extensive leak testing.

In the HTGR context, the equivalent term is "functional containment." Modular HTGRs use multiple barriers to fission product release to form a functional containment that limits release of radionuclides to the environment without the need of a safety class pressure containing building. Functional containment is provided by TRISO coated fuel particles, the fuel matrix, fuel element graphite, the helium pressure boundary, and the reactor building.

RGA evaluations of LWR-type "containment" requirements like those appearing in NUREG-0800 were generally determined to be applicable to at least some degree; the actual extent of LWR containment requirements and guidance applicable to the HTGR plant requires further consideration. Additional design details and interpretation will be required when determining specific HTGR arrangements for things like pressure and leakage control measures for electrical penetrations, isolation valves, and other potential leak paths with respect to credited barriers in HTGR safety case scenarios.

The issue of functional containment performance standards is an NRC policy issue most recently described in SECY-03-0047, "Policy Issues Related to Licensing Non-Light-Water Reactor Designs," SECY-04-0103, "Status of Response to the June 26, 2003, Staff Requirements Memorandum on Policy Issues Related to Licensing Non-Light Water Reactor Designs,"7 SECY-07-0101, "Staff Recommendations Regarding a Risk-Informed and Performance-Based Revision to 10 CFR Part 50 (RIN 3150-AH81),"8 and SECY-10-0034, "Potential Policy, Licensing, and Key Technical Issues for Small Modular Nuclear Reactor Designs."9

\subsubsection{Passive Safety}

Many existing NRC requirements mandate an active response approach to nuclear safety. In other words, positive response actions are expected and required to maintain the integrity of a LWR safety envelope. In contrast, passive safety features rely on inherent physical laws and do not need similar active components and features. The type of passive safety features characteristically present distinguishes HTGR designs from LWR designs. Many active approaches prescribed within NRC regulations and guidance for LWRs may need adaptation in order for their use to be reflected in HTGRs utilizing passive safety design concepts.

Further NRC policy information about passive and inherent safety features in advanced plant designs can be found in SECY-93-087, "Policy, Technical, and Licensing Issues Pertaining to Evolutionary and Advanced Light Water Reactor Designs," ${ }^{10}$ SECY-94-084, "Policy and Technical Issues Associated with 
the Regulatory Treatment of Non-Safety System," ${ }^{11}$ SECY-93-092, "Issues Pertaining to the Advanced Reactor (PRISM, MHTGR, and PIUS) \& CANDU 3 Designs and Their Relationship to Current Regulatory Requirements," "12 and in SECY-10-0034, "Potential Policy, Licensing, and Key Technical Issues for Small Modular Nuclear Reactor Designs."

It is anticipated that HTGRs licensing actions will rely heavily on existing NRC requirements and guidance when addressing the concept of passive safety. Some examples of existing requirements that are supportive of passive safety features include: paragraph (e) of $\$ 50.43$, "Additional Standards and Provisions Affecting Class 103 Licenses and Certifications for Commercial Power" and §50.69, "RiskInformed Categorization and Treatment of Structures, Systems, and Components for Nuclear Power Stations." Other examples include Paragraph (a)(24) of \$52.79, "Contents of Applications; Technical Information in Final Safety Analysis" and SECY-04-0157, "Status of Staff's Proposed Regulatory Structure for New Plant Licensing and Potentially New Policy Issues.” Additional areas relevant to HTGR passive safety include "Best-Estimate Calculations of Emergency Core Cooling System Performance," SRP 6.1.1.2, "Composition and Compatibility of ESF Fluids" and the review requirements contained in paragraph (1) of SRP 6.3, "Emergency Core Cooling System."

\subsubsection{Technology-Specific Language}

Determinations of "Partially Applicable" were common in the presence of LWR-specific language. Such technology-specific regulatory language is a natural product of an NRC licensing process that has historically focused on LWR reviews. SECY-02-0139, "Plan for Resolving Policy Issues Related to Licensing Non-Light Water Reactor Designs,"13 notes this as a nontrivial issue.

Less than $25 \%$ of the items designated as "Partially Applicable" in RGA results call for additional regulatory guidance. That is because many LWR-specific guidance positions may be adapted and applied as written to HTGR licensing actions. This approach supports the NRC position concerning development of an efficient and technology-neutral licensing framework. Further perspective on this can be found in SECY-04-0157, "Status of Staff's Proposed Regulatory Structure for New Plant Licensing and Potentially New Policy Issues," "NUREG-1860, "Feasibility Study for a Risk-Informed and Performance-Based Regulatory Structure for Future Plant Licensing," 15 and in a letter report to the Commissioners, "Development of a Technology-Neutral Regulatory Framework."16

\subsubsection{LWR Design Accident Source Terms}

Several existing regulations (and the guidance pertaining to those regulations) require consideration of postulated releases of radioactive materials from a severe accident. For example, "Reactor Site Criteria" (10 CFR Part 100) requires evaluation of the potential radiological consequences of a postulated fission product release into a containment structure. Furthermore, that postulated release shall assume a substantial core melt and a containment structure that remains intact with maximum allowable design leak rates. Historically, LWRs have also used site-specific parameters (e.g., exclusion area boundaries) and a specified source term into containment for the analysis. Further information on this can be found in Atomic Energy Commission Technical Information Document (TID) TID-14844, "Calculation of Distance Factors for Power and Test Reactor Sites," 17 and NUREG-1465, "Accident Source Terms for Light-Water Nuclear Power Plants."18

The HTGR safety basis supports the same set of regulations as does an LWR safety basis. However, major differences exist between LWRs and HTGRs in that the principal barriers to radionuclide release are quite different. For LWRs, the most limiting severe accident condition is traditionally based on a prescribed large release of radionuclides from failed fuel into containment. The leak tight containment is relied upon to limit the release of the radionuclides to the environment. For the HTGR, the TRISO coated 
fuel particles, the fuel matrix, fuel element graphite, and reactor components are designed to ensure conditions that would result in significant release of radionuclides from the fuel cannot be reached under any circumstance. This is due to the robust nature of the fuel particle, the passive and inherent design characteristics of the reactor, and a core design that maintains fuel temperatures within an acceptable range under all postulated accident conditions. There is no requirement for a leak tight pressure retaining containment building. Accordingly, the prescriptive approach that has traditionally been used to define the source terms for a LWR is not applicable to the modular HTGR.

A summary of modular HTGR characteristics, as well as the regulatory source term interpretations that need clarification between the HTGR and LWR technologies, are described in the NGNP

"Mechanistic Source Terms White Paper."19 This white paper served as the principal resource for RGA source terms applicability determinations.

\subsubsection{Embedded LWR Standards}

A significant portion of LWR-based requirements and guidance includes text specifically drawn from (or referenced to) industry codes and standards that were developed solely for LWRs. For example, NUREG/CR-5973, "Codes and Standards and Other Guidance Cited in Regulatory Documents,"20 identifies a considerable number of LWR-specific codes and standards subsequently referenced in NRC regulations, RGs, and SRP as an approved means of addressing specific topics. A number of regulations that embed LWR standards deal with requirements associated with LWR event sequences or phenomena while others present lists of radionuclides of specific concern to LWR technology. These types of codes and standards may not adequately support an HTGR licensing framework.

The RGA noted the occurrence of embedded LWR standards that were incompatible with HTGRs. Examples of this can be found in 10 CFR §50.55a, "Codes and Standards," 10 CFR §51.51 Table S-3, "Uranium Fuel Cycle Environmental Data," and 10 CFR §51.52 Table S-4, "Environmental Effects of Transportation of Fuel and Waste."

\subsubsection{Risk Metrics}

The existing risk metrics of Core Damage Frequency (CDF) and Large Early Release Frequency (LERF) are LWR-specific and derived from the prescriptive approach applied to evaluation of LWR accident source terms. For reasons cited in Section 2.2.5, these risk metrics do not apply to HTGRs. The definition of proper risk metrics in HTGR licensing is an important yet unresolved issue that must be addressed prior to NRC acceptance of a HTGR COL application. Developing suitable HTGR risk metrics is discussed in a NGNP white paper that presents a proposed approach to selecting appropriate licensing basis events and categorizing them within a risk metric structure consistent with the HTGR safety basis. ${ }^{21}$

\subsubsection{General Design Criteria}

The general design criteria (GDC) presented in Appendix A of 10 CFR Part 50 establish minimum requirements for the principal design criteria relevant to LWR nuclear power plants. The GDCs are also considered to be generally applicable to other types of nuclear power plant designs and provide guidance in establishing the principal design criteria for such other designs.

GDCs do not exist specifically for the design and review of many systems proposed for the modular HTGR in a form approaching those available to LWR technology. The HTGR uses some systems that are very different from LWRs in order to achieve an equivalent function.

The RGA interpreted GDCs and made applicability determinations in the context of current HTGR design understandings. The individual GDC determinations may or may not accurately reflect their 
applicability to a specific future HTGR final design. Each GDC will require an extensive case-by-case review by the applicant(s) to determine relevancy to the end state of design. At a minimum, it is expected that the principal design criteria for modular HTGRs must consider GDCs as guidance and interpret and extend them as appropriate into a specific design capability commitment that includes design, fabrication, construction, testing, and performance requirements for structures, systems, and components (SSC) important to HTGR safety. Departures from an existing GDC must be identified and justified by the applicant(s) at that time.

\subsection{Key Results}

As stated earlier, this report contains three lists of RGA results:

- A summary of potential regulatory changes (Appendix A)

- A summary of additional design information that is needed (Appendix B)

- A table of key HTGR regulatory issues that need further development (Appendix C).

The appendixes highlight regulatory and guidance issues found during the RGA examination that merit further consideration and possible resolution. The contents of these tables are further discussed below.

\subsubsection{Potential Regulatory Changes}

Some NRC regulations and associated guidance documents believed necessary to support modular HTGR licensing may need to be modified, clarified, or expanded prior to their use. The RGA identified 108 instances where such reinterpretation or adaptation may be necessary. Appendix A, Table A-1 identifies 15 existing NRC regulations that merit further evaluation in this regard. Table A-2 notes 93 instances of guidance that might need modification in order to be used in meeting related regulatory requirements. Many of these items were recommended for further consideration because of the LWRspecific language they contained.

A number of items listed in these tables can be decomposed into broad categories of single issues as described below. Some items fall into multiple categories of these common themes.

\subsubsection{Use of Technology-Specific Terms and Definitions}

It has already been noted that LWR technology terms repeatedly appear throughout NRC requirements and guidance documents. Some terms are interchangeable with or are easily adapted to other reactor technologies; these were evaluated in the RGA as technology-neutral. Other terms have meanings very specific to LWRs; it would be inappropriate to literally apply these terms to an HTGR. Some LWR requirements are specifically worded for pressurized water reactors (PWR) or boiling water reactors (BWR) and include specifications for compliance with designated codes and/or standards issued solely for their application. Despite this, many such regulatory statements express an underlying principle that can still be applied to HTGRs.

Examples of existing regulatory or guidance text that includes LWR technology-specific terms needing to be revised, updated, or reinterpreted to provide a HTGR licensing framework include 10 CFR $\$ 50.2$, "Definitions" and Section 3.9.8.II.2.2.6 of NUREG-0800, "Risk Impacts of ISI Changes." Language specifically referencing PWR or BWR operations or systems is exemplified by Appendix E to 10 CFR §50, "Emergency Planning and Preparedness for Production and Utilization Facilities." 


\subsubsection{Requirements Assuming LWR Event Sequences or Phenomena}

Some requirements are associated with LWR event sequences or phenomena. This includes lists of radionuclides specifically oriented to LWR technology. These sequences and phenomena cannot be directly applied to a modular HTGR as currently written and therefore need to be revised or updated prior to their application in an advanced reactor design.

Examples of these requirements include portions of 10 CFR $\$ 50.46$, "Acceptance Criteria for Emergency Core Cooling Systems for Light-Water Nuclear Power Reactors" and 10 CFR $\$ 50$ Appendix K, "ECCS Evaluation Models," 10 CFR $\$ 51.51$ and 10 CFR $§ 51.52$, Tables S-3 and S-4 that respectively deal with environmental effects of the uranium fuel cycle and transportation, and RG-1.174, RG-1.175, RG-1.178, RG-1.182, and RG-1.205 that address various aspects of risk-informed decision-making on important plant systems.

\subsubsection{Threshold Requirements}

Some requirements set thresholds for reporting purposes while others set a minimum level of funding (e.g., decommissioning and liability insurance) but do so using LWR-specific formulations. Similar regulatory perspectives will be needed to accommodate modular HTGRs with due consideration to production and transport of radioactive material.

Examples of these types of regulatory gaps appear in 10 CFR $\$ 50.75$, "Reporting and Recordkeeping for Decommissioning Planning," RG-4.1, "Radiological Environmental Monitoring for Nuclear Power Plants," and DC/COL-ISG-003, "PRA Information to Support Design Certification and Combined License Applications."

\subsubsection{Additional Design Information Needed}

The rationale for using the MHTGR-PSID as the modular HTGR design basis was provided in Section 2.2.1. This document did not provide adequate design insights for all RGA applicability determinations. Consequently, 14 items (one was a regulation) were evaluated as being of indeterminate applicability because supportive design details were lacking. These information gaps are listed in Appendix B, Table B-1, "Summary Table of Additional Design Information Needed."

Because the items listed in Table B-1 are indeterminate, they may or may not be significant to the HTGR licensing framework. The relevance of these positions depends on specific design considerations adopted by the COL applicant and their relevance to safety. Thus, the items reflected in Table B-1 must be re-examined when additional design work has been completed and an applicability determination done in conjunction with the associated COL application.

All of the regulatory positions cited as needing additional design information were considered "Partially Applicable" because, without appropriate design information to the contrary, the item could be considered applicable in the future. Many of these issues should be quickly resolved once necessary design details that support an established safety position become available.

The paragraphs below outline some of the various design information that is still needed with respect to the NGNP RGA.

\subsubsection{Emergency Power Provisions}

The MHTGR-PSID assumed that availability of offsite power was not safety related nor did it classify diesel generators as safety related. The RGA presumed that forthcoming HTGR designs will maintain that position. Consequently, guidance documents like RG-1.9, "Application and Testing of Safety-Related 
Diesel Generators in Nuclear Power Plants," RG-1.93, "Availability of Electric Power Sources," and Branch Technical Positions 8-7, "Criteria for Alarms and Indications Associated with Diesel-Generator Unit Bypassed and Inoperable Status," were determined to not apply. However, this may not be the case for certain uninterrupted power supplies supported by batteries. Further design information is needed to determine the safety classification and related regulatory treatment of certain battery power sources.

\subsubsection{Protective Coatings}

The guidance for use of protective coatings is written explicitly for LWR applications with particular consideration of accident consequences, i.e., post-loss of cooling accident debris. Parts 1, 2 and 4 of RG1.54, "Service Level I, II, and III Protective Coatings Applied to Nuclear Power Plants" and NUREG, Section 6.1.2.1, "Protective Coating Systems (Paints) - Organic Materials," address the use of these protective coatings. Additional design information is needed to confirm or deny the relevance of these guidance documents to HTGRs.

\subsubsection{Reactor Building Leakage}

Overall leak tightness of an HTGR reactor building will impact the applicability of many regulations and guidance items. Paragraph IV.B of Appendix J of 10 CFR 50, "Primary Reactor Containment Leakage Testing for Water-Cooled Power Reactors," lists provisions for periodic testing to meet building leak tightness technical specifications. The applicability of this requirement rests on the final reactor building design and leakage criteria including vent path configuration, filtration requirements and compartmentalization. Similarly, the applicability of Position C.4 of RG-1.13, "Confinement and Filtering Systems," also depends on the final design.

\subsubsection{Instrument Air}

Like diesel generators, the MHTGR-PSID classified instrument and service air systems as nonsafety related. If future HTGR design conforms to this classification, then Sections 9.3.1.2 and 9.3.1.4 of NUREG-0800 Chapter 9.3.1, "Compressed Air System," will not apply. However, if HTGR designs do require these systems to be related to safety, then these documents must be considered.

\subsubsection{Key Regulatory Positions To Be Developed}

The RGA identified a series of broad technical topics unique to HTGRs with no strongly corresponding positions that appear within the current NRC regulatory framework. These topics encompass widely disparate aspects of HTGR design and operation that were noted as similar to existing safety regulations and guidelines but with no comparable HTGR application. Requirements and guidance positions associated with these key topics will likely need development in order to provide a comprehensive HTGR licensing framework.

Table C-1 of Appendix C lists key topics that were identified during the RGA study as needing further regulatory attention. At this time, some Table C-1 items, such as HTGR fuel qualification and the use of high temperature ceramics, are being addressed within the NGNP program and can be applied to HTGR designs in general. ${ }^{22,23}$

\section{USE OF RGA INFORMATION}

A listing of NGNP priority licensing issues and the approaches employed in resolving those issues can be found in the "NGNP Licensing Plan." 24 The RGA was executed in support of and in conformance with this plan. 
The RGA examined those requirements and related documents considered most important to support development of a modular HTGR COL application Format and Content Guide. The Guide will likely be a document similar in content and structure to RG-1.206, "Combined License Applications for Nuclear Power Plants (LWR Edition)."1 The RGA information may also be used to develop a HTGR format and content document dealing with Design Certification and Early Site Permit applications.

It should be remembered that the NGNP RGA study was not scoped to directly support development of a COL application that embraces a specific HTGR final design. It was performed using a generic modular HTGR design model. Nor was it executed with the intention of supporting a revision to the NRC SRP (NUREG-0800). Not all requirements and guidance positions that must be addressed in a HTGR COL application or an update to the SRP were evaluated for applicability in the NGNP RGA. For example, requirements such as "Domestic Licensing of Special Nuclear Material" (10 CFR Part 70), were excluded from the RGA because of their low impact in creating a HTGR COL application Format and Content Guide. Other examples of regulation that would be of interest to future COL applicants and COL application reviewers but were not addressed in the NGNP RGA include 10 CFR §2 "Rules of Practice for Domestic Licensing Proceedings and Issuance of Orders," $\$ 21$ "Reporting of Defects and Noncompliance," §26 “Fitness for Duty Programs," §71 "Packaging and Transportation of Radioactive Materials," §72 "Licensing Requirements... of Spent Nuclear Fuel...," §74 "Material Control and Accounting of Special Nuclear Material," and $\$ 95$ "Facility Security Clearance and Safeguarding of National Security Information and Restricted Data." 


\section{REFERENCES}

1 NRC Regulatory Guide 1.206, "Combined License Applications for Nuclear Power Plants, (LWR Edition)" June 2007.

2 NGNP-LIC-ETR-PROC-0001, "Procedure for Performing the Regulatory Gap Analysis," Revision 1, August 2010.

3 DOE-HTGR-86-024, "Preliminary Safety Information Document for the Standard MHTGR," Amendment 13, August 7, 1992.

4 NUREG-1338 (draft), "Draft Preapplication Safety Evaluation Report for the Modular HighTemperature Gas-Cooled Reactor," March 1989.

5 NUREG-1338, "Preapplication Safety Evaluation Report for the Modular High-Temperature GasCooled Reactor (MHTGR),” December 1995.

6 SECY-03-0047, "Policy Issues Related to Licensing Non-Light-Water Reactor Designs," June 26, 2003.

7 SECY-04-0103, "Status of Response to the June 26, 2003, Staff Requirements Memorandum on Policy Issues Related to Licensing Non-Light Water Reactor Designs,” June 23, 2004.

8 SECY-07-0101, "Staff Recommendations Regarding a Risk-Informed and Performance-Based Revision to 10 CFR Part 50 (RIN 3150-AH81),"June 14, 2007.

9 SECY-10-0034, "Potential Policy, Licensing, and Key Technical Issues for Small Modular Nuclear Reactor Designs," March 28, 2010.

10 SECY-93-087, "Policy, Technical, and Licensing Issues Pertaining to Evolutionary and Advanced Light Water Reactor Designs," April 5, 1993.

11 SECY-94-084, "Policy and Technical Issues Associated with the Regulatory Treatment of Non-Safety System," March 28, 1994.

12 SECY-93-092, "Issues Pertaining to the Advanced Reactor (PRISM, MHTGR, and PIUS) \& CANDU 3 Designs and Their Relationship to Current Regulatory Requirements," April 8, 1993.

13 SECY-02-0139, "Plan for Resolving Policy Issues Related to Licensing Non-Light Water Reactor Designs," July 22, 2002.

14 SECY-04-0157, "Status of Staff's Proposed Regulatory Structure for New Plant Licensing and Potentially New Policy Issues," August 30, 2004.

15 NUREG-1860, "Feasibility Study for a Risk-Informed and Performance-Based Regulatory Structure for Future Plant Licensing," December 2007.

16 Letter from Advisory Committee on Reactor Safeguards to D. E. Klein, "Development of a Technology-Neutral Regulatory Framework,” ACRSR-2267, September 26, 2007.

17 TID-14844, "Calculation of Distance Factors for Power and Test Reactor Sites," Technical Information Document (TID) 14844, March 1962.

18 NUREG-1465, “Accident Source Terms for Light-Water Nuclear Power Plants,” February 1995.

19 INL/EXT-10-17997, “Mechanistic Source Terms White Paper,” Revision 0, July 2010.

20 NUREG/CR-5973, "Codes and Standards and Other Guidance Cited in Regulatory Documents," Revision 3, PNL-8462, August 1996. 
21 INL/EXT-10-19521, "Next Generation Nuclear Plant Licensing Basis Event Selection White Paper," September 2010.

22 INL/EXT-10-18610, "NGNP Fuel Qualification White Paper," Revision 0, July 2010.

23 INL/EXT-09-17187, "NGNP High Temperature Material White Paper," June 2010.

24 PLN-3202, "NGNP Licensing Plan,” Revision 0, June 2009. 
Appendix A

\section{Summary Table of Potential Regulatory Changes}




\section{Appendix A \\ Summary Table of Potential Regulatory Changes}

Below are 15 existing regulations (Table A-1) and 93 existing guidance positions (Table A-2) identified by the RGA as important to the HTGR licensing framework but may require some adjustment, adaptation, or reinterpretation prior to their use in a modular HTGR licensing action. The items were determined to be at least partially applicable using MHTGR-PSID design information. Resolution of many items will require additional HTGR design and operation information.

Table A-1. Potential Changes to Regulations.

\begin{tabular}{|c|c|c|}
\hline Citation. & Summary of Existing Regulation & Identified Change \\
\hline 10CFR50.2 & $\begin{array}{l}10 \text { CFR } 50.2 \text { presents definitions } \\
\text { associated with light-water reactors } \\
\text { (LWRs). }\end{array}$ & $\begin{array}{l}\text { Entries such as "reactor coolant pressure } \\
\text { boundary" may need clarification and/or } \\
\text { refinement to reflect the specific attributes of } \\
\text { High-Temperature Gas-Cooled Reactors (HTGRs). }\end{array}$ \\
\hline $\begin{array}{l}\text { 10CFR50.46(a) } \\
\text { 10CFR50.46(b) }\end{array}$ & $\begin{array}{l}\text { §50.46 address acceptance criteria for } \\
\text { LWR Emergency Core Cooling } \\
\text { Systems (ECCS). The HTGR does not } \\
\text { have an ECCS but uses other passive } \\
\text { core cooling systems. }\end{array}$ & $\begin{array}{l}\text { An amendment to } \$ 50.46 \text { may be needed to detail } \\
\text { requirements for calculating the performance of } \\
\text { the HTGR cooling. This also impacts Appendix K } \\
\text { of Part } 50 \text { and Standard Review Plan (SRP) } 6.3 .1 \text {. }\end{array}$ \\
\hline 10CFR50.54 & $\begin{array}{l}\S 50.54(\mathrm{~m}) \text { contains a table listing the } \\
\text { minimum number of licensed operators } \\
\text { required for LWR power plants based } \\
\text { on the number of units and control } \\
\text { rooms at a site. }\end{array}$ & $\begin{array}{l}\text { The table provided in } \S 50.54(\mathrm{~m}) \text { may need update } \\
\text { to reflect licensed operator requirements for } \\
\text { passively safe HTGR plants. It is likely that the } \\
\text { licensed operator requirements will differ from } \\
\text { LWRs. }\end{array}$ \\
\hline $\begin{array}{l}\text { 10CFR50.68(a) } \\
10 \mathrm{CFR} 50.68(\mathrm{~b})\end{array}$ & $\begin{array}{l}\S 50.68(\mathrm{a}) \text { and }(\mathrm{b}) \text { contain detailed } \\
\text { requirements that ensure LWR spent } \\
\text { fuel pools are maintained subcritical. }\end{array}$ & $\begin{array}{l}\text { HTGR spent fuel will have characteristics } \\
\text { substantially different than spent LWR fuel. } \\
\text { Similarly requirements for HTGRs may be needed } \\
\text { to ensure subcriticality and adequate cooling. }\end{array}$ \\
\hline 10CFR50.75 & $\begin{array}{l}\S 50.75 \text { includes a table and formulas } \\
\text { that detail how to calculate the escrow } \\
\text { funds needed for plant } \\
\text { decommissioning. }\end{array}$ & $\begin{array}{l}\text { The table at } \S 50.75(\mathrm{~b}) \text { needs to accommodate } \\
\text { HTGRs or } \S 50.75(\mathrm{c}) \text { should be made applicable to } \\
\text { power reactors such as HTGRs. }\end{array}$ \\
\hline 10CFR50, App. E & $\begin{array}{l}\text { App E provides requirements for } \\
\text { emergency planning and preparedness } \\
\text { for nuclear reactors. The requirements } \\
\text { are mostly general but do reference } \\
\text { specific LWR designs. }\end{array}$ & $\begin{array}{l}\text { The underlying principles apply equally to LWRs } \\
\text { and HTGRs. However, the appendix specifically } \\
\text { identifies pressurized water reactor (PWR) and } \\
\text { boiling water reactor (BWR) requirements (see } \\
\text { examples in Section VI(2)(a) (i) and (ii)). The } \\
\text { appendix should be reviewed to determine updates } \\
\text { needed to address HTGRs. }\end{array}$ \\
\hline 10CFR50, App. I & $\begin{array}{l}\text { App I explicitly address objectives for } \\
\text { monitoring and meeting as low as } \\
\text { reasonably achievable limits for LWR } \\
\text { effluents. }\end{array}$ & $\begin{array}{l}\text { The requirements in App I can be applied to } \\
\text { HTGRs. However, the text in the appendix may } \\
\text { need clarification to reflect specific HTGR } \\
\text { requirements. }\end{array}$ \\
\hline
\end{tabular}




\begin{tabular}{|c|c|c|}
\hline Citation. & Summary of Existing Regulation & Identified Change \\
\hline 10CFR50, App. J & $\begin{array}{l}\text { App J describes in a relatively specific } \\
\text { manner how an LWR containment } \\
\text { structure must be tested for leaks. } \\
\text { Section II.A describes "primary reactor } \\
\text { containment" as "an essentially leak } \\
\text { tight barrier against the uncontrolled } \\
\text { release of radioactivity to the } \\
\text { environment." }\end{array}$ & $\begin{array}{l}\text { LWR primary reactor containment is expected to } \\
\text { be an "essentially leak-tight barrier" for } \\
\text { radionuclide release. HTGRs meet regulatory } \\
\text { requirements for protection of the public and the } \\
\text { environment with a multi-barrier functional } \\
\text { containment system. Existing regulations will need } \\
\text { to be adapted to address testing of the various } \\
\text { HTGR functional containment elements. }\end{array}$ \\
\hline 10CFR50, App. K & $\begin{array}{l}\text { App K provides specifics about how to } \\
\text { calculate the effects of a Loss of } \\
\text { Coolant Accident (LOCA) event in } \\
\text { LWRs. }\end{array}$ & $\begin{array}{l}\text { The underlying principles of App. K, which cover } \\
\text { the evaluation of core heat generation and } \\
\text { associated heat removal capabilities, will need to } \\
\text { be addressed for HTGRs. Design and analytical } \\
\text { methods work is required to establish the content } \\
\text { and structure of similar requirements for HTGRs. }\end{array}$ \\
\hline 10CFR51.51 & $\begin{array}{l}\text { Table S-3 in } \S 51.51 \text { provides data to } \\
\text { calculate the environmental impact of } \\
\text { the nuclear fuel cycle. It is based on the } \\
\text { use of LWR fuel. }\end{array}$ & $\begin{array}{l}\text { Table S-3, "Uranium Fuel Cycle Environmental } \\
\text { Data," for LWRs should be evaluated and revised } \\
\text { as appropriate to better reflect the impacts of the } \\
\text { HTGR nuclear fuel cycle. }\end{array}$ \\
\hline 10CFR51.52 & $\begin{array}{l}\text { Table S- } 4 \text { in } \S 51.52 \text { provides data to } \\
\text { calculate the environmental impact of } \\
\text { the transport of fuel to and from a } \\
\text { single LWR. }\end{array}$ & $\begin{array}{l}\text { Table S-4, "Environmental Effects of } \\
\text { Transportation of Fuel and Waste" for LWRs } \\
\text { should be evaluated and, if necessary, revised to } \\
\text { reflect the impacts of transporting fuel to and from } \\
\text { a HTGR. }\end{array}$ \\
\hline 10CFR51, App. B & $\begin{array}{l}10 \text { CFR } 51 \text { App B summarizes the } \\
\text { environmental impacts of renewing the } \\
\text { license for a LWR. }\end{array}$ & $\begin{array}{l}\text { Once actual HTGR operating experience is } \\
\text { accumulated, App B should be supplemented to } \\
\text { reflect actual HTGR impacts on environmental } \\
\text { resources for license renewal purposes. }\end{array}$ \\
\hline 10CFR55.59(c)(3)(i) & $\begin{array}{l}\S 55.59(\mathrm{c})(3)(\mathrm{i}) \text { lists actions that } \\
\text { operators must perform to maintain a } \\
\text { license. Some of the actions listed are } \\
\text { specific to LWRs and have no HTGR } \\
\text { equivalent. }\end{array}$ & $\begin{array}{l}\text { Updated information will be needed for HTGRs } \\
\text { where only LWR specificity is provided. This } \\
\text { issue will be resolved based on additional design } \\
\text { details. }\end{array}$ \\
\hline
\end{tabular}


Table A-2. Potential Changes to Guidance.

\begin{tabular}{|c|c|c|}
\hline Citation & Summary of Existing Guidance & Identified Change \\
\hline RG-1.20 & $\begin{array}{l}\text { The Regulatory Guide (RG) describes a } \\
\text { program to evaluate vibrations in LWRs } \\
\text { during preoperational testing. }\end{array}$ & $\begin{array}{l}\text { HTGR specific language and approaches need } \\
\text { to be adopted which address vibrations induced } \\
\text { by helium flow, turbulence, etc. }\end{array}$ \\
\hline RG-1.25 & $\begin{array}{l}\text { The RG provides assumptions to be used to } \\
\text { evaluate a fuel handling accident for an } \\
\text { LWR. }\end{array}$ & $\begin{array}{l}\text { Specifics should be developed for HTGR fuel } \\
\text { handling accidents once appropriate design } \\
\text { details become available. The RG is written } \\
\text { explicitly for LWRs but the principles apply to } \\
\text { HTGRs. The NGNP "Mechanistic Source } \\
\text { Terms White Paper" cites RG-1.183 as } \\
\text { pertinent NRC guidance for HTGR mechanistic } \\
\text { source terms. }\end{array}$ \\
\hline $\begin{array}{l}\text { RG-1.27.C.1 } \\
\text { RG-1.27.C.2 } \\
\text { RG-1.27.C.3 } \\
\text { RG-1.27.C.4 }\end{array}$ & $\begin{array}{l}\text { RG-1.27 describes the requirements of the } \\
\text { ultimate heat sink for an LWR, focusing } \\
\text { exclusively on cooling water. }\end{array}$ & $\begin{array}{l}\text { The current edition of RG-1.27 (Rev. 2, Jan } \\
\text { 1976) was released for comment but has not } \\
\text { been updated to address alternatives to water as } \\
\text { the ultimate heat sink. Accommodations must } \\
\text { be made to address HTGR applications. (The } \\
\text { review of SRP 2.3.1.5 recommended a change } \\
\text { to RG-1.27.) }\end{array}$ \\
\hline RG-1.29.C.1 & $\begin{array}{l}\text { The RG lists the LWR structures, systems, } \\
\text { and components (SSCs) that are designated } \\
\text { as Seismic Category I. }\end{array}$ & $\begin{array}{l}\text { Some of the listed SSCs have no equivalent in } \\
\text { an HTGR. Other HTGR-specific SSCs may be } \\
\text { missing. Once appropriate design details } \\
\text { become known, SSCs listed in sections (a-q) } \\
\text { need review and adaptation as necessary to be } \\
\text { applicable. }\end{array}$ \\
\hline $\begin{array}{l}\text { RG-1.45, } 1 \\
\text { RG-1.45, } 2 \\
\text { RG-1.45, } 3\end{array}$ & $\begin{array}{l}\text { The RG describes methods to implement } \\
\text { requirements to select reactor coolant } \\
\text { leakage detection systems, monitor for } \\
\text { leakage, and respond to leaks. }\end{array}$ & $\begin{array}{l}\text { The RG applies to LWRs but also contains an } \\
\text { underlying intent applicable to HTGRs. Further } \\
\text { consideration on the significance of and } \\
\text { approaches to leakage monitoring in an HTGR } \\
\text { will be necessary once supporting design } \\
\text { information details become available. }\end{array}$ \\
\hline RG-1.63 & $\begin{array}{l}\text { The RG states that conforming to IEEE Std } \\
317-1983 \text { is sufficient to meet NRC's } \\
\text { regulations with respect to design, } \\
\text { construction, testing, qualification, and } \\
\text { installation of electric penetration } \\
\text { assemblies in containment structures for } \\
\text { nuclear power plants. }\end{array}$ & $\begin{array}{l}\text { Electrical penetrations will be required in a } \\
\text { HTGR. However, the exact type of penetration } \\
\text { that will be used is currently unknown. } \\
\text { Additional design understanding is needed to } \\
\text { properly link these criteria to acceptable rates } \\
\text { of leakage. }\end{array}$ \\
\hline RG-1.68 & $\begin{array}{l}\text { App A to this RG lists the plant SSCs and } \\
\text { the design features and performance } \\
\text { capabilities that should be demonstrated } \\
\text { during the Initial Test Program. }\end{array}$ & $\begin{array}{l}\text { An HTGR version of App A should be adopted } \\
\text { as equivalent guidance. Further design details } \\
\text { will be needed to resolve this issue. }\end{array}$ \\
\hline RG-1.68.2 & $\begin{array}{l}\text { RG-1.68.2 discusses pre-op testing for } \\
\text { LWRs and includes testing with the turbine } \\
\text { generator online. This RG does not } \\
\text { recognize cogeneration plants or plants that } \\
\text { may not have a turbine generator ( no } \\
\text { electricity production). }\end{array}$ & $\begin{array}{l}\text { This RG should be adapted to accommodate } \\
\text { HTGR configurations, particularly for non- } \\
\text { power generating or co-generation } \\
\text { configurations. }\end{array}$ \\
\hline
\end{tabular}




\begin{tabular}{|c|c|c|}
\hline Citation & Summary of Existing Guidance & Identified Change \\
\hline RG-1.101 & $\begin{array}{l}\text { Three versions of this RG that are in effect: } \\
\text { Rev } 3, \text { Rev } 4 \text { and Rev } 5 \text { - each address } \\
\text { different topics regarding emergency } \\
\text { planning. }\end{array}$ & $\begin{array}{l}\text { Additional insight and agreement is } \\
\text { recommended to address specific HTGR } \\
\text { attributes. For example, Rev } 5 \text { contains } \\
\text { emergency planning requirements that may not } \\
\text { be applicable to HTGRs due to reduced source } \\
\text { terms and plume exposure pathways. An } \\
\text { approach to the HTGR planning zone is } \\
\text { presented in a related NGNP white paper. }\end{array}$ \\
\hline RG-1.110 & $\begin{array}{l}\text { The RG provides guidance (including costs) } \\
\text { for LWR-typical equipment and systems } \\
\text { and how to calculate the cost-benefit } \\
\text { analysis for radionuclide clean-up systems. }\end{array}$ & $\begin{array}{l}\text { The equipment and systems listed in App A of } \\
\text { RG-1.110 are specific to that used to control } \\
\text { releases from an LWR. Once design details } \\
\text { become available, this list and associated costs } \\
\text { should be augmented with equipment and } \\
\text { systems that would be used to control HTGR } \\
\text { release types. }\end{array}$ \\
\hline RG-1.112 & $\begin{array}{l}\text { The RG references NUREGs-0016 and - } \\
0017 \text { (which are specific to BWRs and } \\
\text { PWRs, respectively), for the calculation of } \\
\text { radioactive source terms. }\end{array}$ & $\begin{array}{l}\text { Additional guidance should be developed and } \\
\text { adopted that is specific to HTGRs and serves a } \\
\text { function similar to what is available to BWRs } \\
\text { (NUREG-0016) \& PWRs (NUREG-0017). An } \\
\text { approach to this issue has already been } \\
\text { described in a NGNP white paper. }\end{array}$ \\
\hline RG-1.113 & $\begin{array}{l}\text { The RG describes calculation models for } \\
\text { estimating aquatic dispersion of radioactive } \\
\text { material from an LWR to a surface water } \\
\text { body. }\end{array}$ & $\begin{array}{l}\text { The guide presents radioactive effluent limits for } \\
\text { a LWR. Although the underlying intent is } \\
\text { applicable to a HTGR, the final HTGR design } \\
\text { may indicate different release limits to be more } \\
\text { appropriate. Additional design information will } \\
\text { be required for resolution of this issue. }\end{array}$ \\
\hline RG-1.133 & $\begin{array}{l}\text { The RG describes a method for } \\
\text { implementing requirements with respect to } \\
\text { detecting a loose part in LWRs during } \\
\text { normal operation. }\end{array}$ & $\begin{array}{l}\text { Once appropriate design details become } \\
\text { available, the RG will need update to address } \\
\text { HTGR factors. Measurement locations and } \\
\text { sensitivities for the HTGR would not be the } \\
\text { same as the LWR. }\end{array}$ \\
\hline $\begin{array}{l}\text { RG-1.147 } \\
\text { RG-1.192 }\end{array}$ & $\begin{array}{l}\text { RG-1.147 contains a list of NRC-approved } \\
\text { American Society of Mechanical Engineers } \\
\text { (ASME) Section XI code cases for In- } \\
\text { Service Inspection (ISI). RG-1.192 contains } \\
\text { a list of ASME Operation and Maintenance } \\
\text { (O\&M) Code Cases approved by NRC. All } \\
\text { code cases are based on LWR designs. }\end{array}$ & $\begin{array}{l}\text { To support ISI and O\&M inspections for the } \\
\text { HTGR, selected code cases accepted by the } \\
\text { NRC for LWRs may require approval for the } \\
\text { HTGR. Additional new code cases may be } \\
\text { required for specific HTGR ISI requirements. } \\
\text { More design details will be needed to fully } \\
\text { resolve this issue. }\end{array}$ \\
\hline RG-1.174 & $\begin{array}{l}\text { The RG provides recommendations for use } \\
\text { of risk information in support of licensing } \\
\text { basis changes. }\end{array}$ & $\begin{array}{l}\text { Alternative metrics to Core Damage Frequency } \\
\text { (CDF) and Large Early Release Frequency } \\
\text { (LERF) need to be developed and adopted in } \\
\text { order to make this RG relevant for HTGRs. An } \\
\text { approach to this issue is contained in a NGNP } \\
\text { white paper on Licensing Basis Event } \\
\text { selection. }\end{array}$ \\
\hline RG-1.175 & $\begin{array}{l}\text { The RG provides recommendations for use } \\
\text { of risk information in support of risk } \\
\text { informed in-service testing. }\end{array}$ & $\begin{array}{l}\text { Alternative metrics to CDF and LERF should } \\
\text { be developed and adapted in order to make this } \\
\text { RG relevant for HTGRs. An approach to this } \\
\text { issue is contained in a NGNP white paper on } \\
\text { Licensing Basis Event selection. }\end{array}$ \\
\hline
\end{tabular}




\begin{tabular}{|c|c|c|}
\hline Citation & Summary of Existing Guidance & Identified Change \\
\hline RG-1.178 & $\begin{array}{l}\text { RG provides recommendations on } \\
\text { acceptable approaches to meeting the } \\
\text { existing Section XI requirements for the } \\
\text { scope and frequency of inspection of ISI } \\
\text { programs. }\end{array}$ & $\begin{array}{l}\text { This RG is generic and is applicable to LWRs } \\
\text { and HTGRs but does not reference risk metrics } \\
\text { appropriate to HTGRs. Alternative metrics to } \\
\text { CDF and LERF should be developed and } \\
\text { adapted in order to make this RG relevant for } \\
\text { HTGRs. An approach to this issue is contained } \\
\text { in a NGNP white paper on Licensing Basis } \\
\text { Event selection. }\end{array}$ \\
\hline RG-1.182 & $\begin{array}{l}\text { This } R G \text { provides guidance on assessing and } \\
\text { managing risks prior to maintenance } \\
\text { activities. }\end{array}$ & $\begin{array}{l}\text { Alternative metrics to CDF should be } \\
\text { developed and adapted in order to make this } \\
\text { RG relevant for HTGRs. An approach to this } \\
\text { issue is contained in a NGNP white paper on } \\
\text { Licensing Basis Event selection. }\end{array}$ \\
\hline RG-1.186 & $\begin{array}{l}\text { This RG provides guidelines and examples } \\
\text { for identifying } 10 \text { CFR } 50.2 \text { design bases. }\end{array}$ & $\begin{array}{l}\text { Appendix B to NEI 97-04, provides "Guidance } \\
\text { and Examples for Identifying } 10 \text { CFR } 50.2 \\
\text { Design Bases" using only LWR examples. } \\
\text { Equivalent examples for HTGRs will be needed. } \\
\text { Additional design details are necessary to } \\
\text { address this need. New examples may be } \\
\text { required. }\end{array}$ \\
\hline RG-1.195 & $\begin{array}{l}\text { The RG provides guidance on acceptable } \\
\text { methods and assumptions for performing } \\
\text { evaluations of fission product releases and } \\
\text { radiological consequences of several } \\
\text { postulated LWR design basis accidents. }\end{array}$ & $\begin{array}{l}\text { Modeling approaches and source terms should } \\
\text { be developed based on new design basis } \\
\text { accidents and new source term methodology that } \\
\text { will be developed for the HTGR. }\end{array}$ \\
\hline RG-1.202 & $\begin{array}{l}\text { The RG provides the standard format and } \\
\text { content for cost estimates in } \\
\text { decommissioning LWRs. }\end{array}$ & $\begin{array}{l}\text { Once HTGR design details become known, the } \\
\text { content of RG- } 1.202 \text { guidance should be } \\
\text { expanded to include items and issues that are } \\
\text { specific to HTGRs and without equivalence to } \\
\text { LWRs. }\end{array}$ \\
\hline RG-1.205 & $\begin{array}{l}\text { The RG provides guidance for use in } \\
\text { complying with NRC requirements } \\
\text { promulgated for risk-informed, } \\
\text { performance-based Fire Protection } \\
\text { Programs (FPPs). }\end{array}$ & $\begin{array}{l}\text { CDF and LERF are not the right metric for the } \\
\text { HTGR fire risk evaluation. Additional guidance } \\
\text { on the appropriate metrics is required. An } \\
\text { approach to this issue is contained in a NGNP } \\
\text { white paper on Licensing Basis Event } \\
\text { selection. }\end{array}$ \\
\hline $\begin{array}{l}\text { RG-4.1, Rev 2, } \\
\text { RG-4.1.C.2, } \\
\text { RG-4.1.C.3, } \\
\text { RG-4.1.C.4, } \\
\text { RG-4.1.C.5, } \\
\text { RG-4.1.C.6, } \\
\text { RG-4.1.C.7, } \\
\text { RG-4.1.C.9, } \\
\text { RG-4.1.C.10 } \\
\text { RG-4.1.C.11. }\end{array}$ & $\begin{array}{l}\text { The RG describes a method considered } \\
\text { acceptable for use in establishing and } \\
\text { conducting an environmental monitoring } \\
\text { program at nuclear power plants. The guide } \\
\text { describes programs for preoperational and } \\
\text { operational environmental monitoring. }\end{array}$ & $\begin{array}{l}\text { The RG repeatedly refers to NUREG- } \\
\text { 1301/1302, which apply specifically to PWRs } \\
\text { and BWRs, respectively. Once supporting } \\
\text { HTGR design information becomes available, } \\
\text { an HTGR guidance document with an } \\
\text { equivalent content to NUREG-1301/1302 is } \\
\text { needed. }\end{array}$ \\
\hline RG-4.1.C.7 & $\begin{array}{l}\text { The RG also describes programs for } \\
\text { preoperational and operational } \\
\text { environmental monitoring that also } \\
\text { specifically address C-14. }\end{array}$ & $\begin{array}{l}\text { Supplementary guidance for environmental } \\
\text { monitoring at an HTGR facility may be needed. } \\
\text { Paragraph (d) may need revision to address C- } \\
14 \text { emissions from an HTGR. }\end{array}$ \\
\hline
\end{tabular}




\begin{tabular}{|c|c|c|}
\hline Citation & Summary of Existing Guidance & Identified Change \\
\hline RG-4.2 & $\begin{array}{l}\text { The RG provides a format that is } \\
\text { recommended for submittal of required } \\
\text { environmental information. }\end{array}$ & $\begin{array}{l}\text { The RG references outdated regulations and } \\
\text { contains several appendices (i.e., E, F and G) } \\
\text { with data requirements specific to LWRs. The } \\
\text { RG should be advanced to reflect current } \\
\text { regulations and add similar data requirements } \\
\text { for HTGRs. This is a generic observation and } \\
\text { not specifically an HTGR issue. }\end{array}$ \\
\hline RG-4.7.C.5 & $\begin{array}{l}\text { The RG discusses the major site } \\
\text { characteristics related to public health and } \\
\text { safety and environmental issues considered } \\
\text { in determining the suitability of sites for } \\
\text { LWRs. The guidelines may be used by } \\
\text { applicants in identifying suitable candidate } \\
\text { sites. }\end{array}$ & $\begin{array}{l}\text { Further insight and guidance is necessary to } \\
\text { clarify the exemption provided to a HTGR in } \\
10 \text { CFR } 50.47 \text {, which allows the emergency } \\
\text { planning zone to be established on a case-by- } \\
\text { case basis for HTGRs. The issue is further } \\
\text { discussed in an NGNP white paper. }\end{array}$ \\
\hline $\begin{array}{l}\text { NUREG-0800 } \\
2.1 .3 .1\end{array}$ & $\begin{array}{l}\text { This section of the SRP provides guidance } \\
\text { on how population data should be presented } \\
\text { in the Safety Analysis Report by referencing } \\
\text { RG-1.70 and DG-1145. }\end{array}$ & $\begin{array}{l}\text { As draft regulatory guide DG- } 1145 \text { is now } \\
\text { superseded by the final version, this section } \\
\text { should be updated to reference RG-1.206 and } \\
\text { any other HTGR or technology neutral } \\
\text { guidance that has been developed. }\end{array}$ \\
\hline $\begin{array}{l}\text { NUREG-0800 } \\
2.3 .1 .5\end{array}$ & $\begin{array}{l}\text { This section of the SRP provides guidance } \\
\text { on how to present climatology data } \\
\text { associated with the ultimate heat sink, } \\
\text { specifically water. }\end{array}$ & $\begin{array}{l}\text { RG-1.27 should be extended or appended to } \\
\text { address heat exchange to mediums other than } \\
\text { water as the ultimate heat sink. See also } \\
\text { comment for RG-1.27.C.1. }\end{array}$ \\
\hline $\begin{array}{l}\text { NUREG-0800 } \\
2.5 \cdot 2.4 \\
2.5 .2 .5 \\
2.5 .2 .6\end{array}$ & $\begin{array}{l}\text { These SRP sections describe requirements } \\
\text { for providing site ground motion data. All } \\
\text { reference RG-1.165, which has been } \\
\text { superseded by RG-1.208, which is also } \\
\text { referenced. }\end{array}$ & $\begin{array}{l}\text { Application of these sections should reflect the } \\
\text { withdrawal of RG-1.165. This is a generic issue } \\
\text { not limited to HTGR licensing. }\end{array}$ \\
\hline $\begin{array}{l}\text { NUREG-0800 } \\
\text { 3.9.8 II.2.2.6 }\end{array}$ & $\begin{array}{l}\text { This section of the SRP discusses the } \\
\text { methods for calculating the risk impacts of } \\
\text { ISI changes and references RG-1.174, } \\
\text { which makes use of CDF. }\end{array}$ & $\begin{array}{l}\text { New or revised regulatory insights need to be } \\
\text { developed that provide for alternative HTGR } \\
\text { risk metrics in lieu of CDF and LERF as } \\
\text { currently defined for LWRs. See comment on } \\
\text { RG-1.174 and the NGNP white paper on } \\
\text { Licensing Basis Event selection. }\end{array}$ \\
\hline $\begin{array}{l}\text { NUREG-0800 } \\
3.11 .4\end{array}$ & $\begin{array}{l}\text { This section of the SRP lists the referenced } \\
\text { standards and regulatory guides that are } \\
\text { acceptable to NRC for environmental } \\
\text { qualification of electrical penetrations. }\end{array}$ & $\begin{array}{l}\text { Greater design understanding and agreement is } \\
\text { required for details concerning electrical } \\
\text { penetration at the boundary of a reactor } \\
\text { building that is not ASME III, Div } 2 \\
\text { containment structure. Additional insight is } \\
\text { required for electrical penetration details in a } \\
\text { HTGR-specific design once those details and } \\
\text { leakage criteria become known. See also } \\
\text { comment for RG-1.63. }\end{array}$ \\
\hline $\begin{array}{l}\text { NUREG-0800 } \\
\text { BTP 5-3.4 }\end{array}$ & $\begin{array}{l}\text { The purpose of this Branch Technical } \\
\text { Position (BTP) is to summarize the } \\
\text { requirements regarding fracture toughness, } \\
\text { pressure-temperature limits, material } \\
\text { surveillance, and pressurized thermal shock } \\
\text { and provide guidance, as necessary. }\end{array}$ & $\begin{array}{l}\text { Pressurized thermal shock screening criteria } \\
\text { provided for BWRs in Line (2) of this item } \\
\text { should be adapted and clarified to be more } \\
\text { generic and accommodate design details that } \\
\text { cover HTGRs. }\end{array}$ \\
\hline
\end{tabular}




\begin{tabular}{|c|c|c|}
\hline Citation & Summary of Existing Guidance & Identified Change \\
\hline $\begin{array}{l}\text { NUREG-0800 } \\
6.1 .1 .2\end{array}$ & $\begin{array}{l}\text { The SRP lists the quality requirements for } \\
\text { engineered safety feature (ESF) fluids. }\end{array}$ & $\begin{array}{l}\text { This item addresses "Composition and } \\
\text { Compatibility of ESF Fluids," that are very } \\
\text { specific to LWRs. HTGRs rely on a five barrier } \\
\text { concept for functional containment. Further } \\
\text { interpretation is needed concerning the } \\
\text { requirements applicable to General Design } \\
\text { Criteria (GDC) GDC } 41 .\end{array}$ \\
\hline $\begin{array}{l}\text { NUREG-0800 } \\
6.2 .1 .3 .1\end{array}$ & $\begin{array}{l}\text { The SRP lists the sources of stored and } \\
\text { generated energy that should be considered } \\
\text { in analyses of LOCAs. Many of these are } \\
\text { specific to LWRs with no equivalence to } \\
\text { systems in an HTGR. }\end{array}$ & $\begin{array}{l}\text { Interpretations of these acceptance criteria } \\
\text { should be expanded to cover the HTGR. } \\
\text { Depressurized LOFC events will be postulated } \\
\text { for the HTGR. Specific events will be } \\
\text { established through combination of the design } \\
\text { and the licensing basis event selection } \\
\text { processes. Since stored energy in helium } \\
\text { coolant is much lower, more design detail will } \\
\text { be needed to resolve this issue. }\end{array}$ \\
\hline $\begin{array}{l}\text { NUREG-0800 } \\
6.2 .4 .22\end{array}$ & $\begin{array}{l}\text { This section addresses the function of the } \\
\text { containment isolation system. The item } \\
\text { references App. K of } 10 \text { CFR } 50 \text { regarding } \\
\text { source term in the event of a LOCA. }\end{array}$ & $\begin{array}{l}\text { This item addresses determination of the extent } \\
\text { of fuel failure (source term) in radiological } \\
\text { calculations. The underlying principles of App. } \\
\text { K (calculating core heat generation and core } \\
\text { heat removal) appear to apply, but adjustment } \\
\text { will be required to account for the HTGR } \\
\text { TRISO fuel and multi-barrier functional } \\
\text { containment design. See related comment on } \\
\text { Part } 50 \text { App K. }\end{array}$ \\
\hline $\begin{array}{l}\text { NUREG-0800 } \\
6.2 .6 .1\end{array}$ & $\begin{array}{l}\text { The SRP describes the review requirements } \\
\text { for the reactor containment leakage rate } \\
\text { testing program for conformance to } 10 \mathrm{CFR} \\
\text { Part 50, Appendix J, and GDC 52, 53, and } \\
54 \text {. }\end{array}$ & $\begin{array}{l}\text { The HTGR functional containment consists of } \\
\text { five radionuclide retention barriers. The two } \\
\text { outermost barriers are the Helium Pressure } \\
\text { Boundary and the Reactor Building. The safety } \\
\text { analysis presented in the MHTGR-PSID } \\
\text { credits fuel design with meeting 10CFR100 } \\
\text { limits without taking credit for either of the two } \\
\text { outer barriers. However, depending on details } \\
\text { of HTGR design and the postulated events } \\
\text { being evaluated, these barriers may be credited } \\
\text { in the future. Establishment of applicable } \\
\text { barrier leak testing requirements would be } \\
\text { subject to details about overall leak tightness, } \\
\text { vent path configuration, filtration requirements, } \\
\text { and compartmentalization. Additional design } \\
\text { development will be needed to determine } \\
\text { appropriate leak tightness requirements. }\end{array}$ \\
\hline $\begin{array}{l}\text { NUREG-0800 } \\
6.3 .1\end{array}$ & $\begin{array}{l}\text { The SRP describes the review requirements } \\
\text { for the information presented in the } \\
\text { applicant's safety analysis report regarding } \\
\text { the ECCS. }\end{array}$ & $\begin{array}{l}\text { The underlying principle of protecting the core } \\
\text { is applicable to an HTGR. The specific } \\
\text { guidance and methods (i.e., ECCS) would not } \\
\text { apply to the HTGR. Specific guidance for } \\
\text { conservative HTGR models on passive cooling } \\
\text { must be developed and approved. }\end{array}$ \\
\hline
\end{tabular}




\begin{tabular}{|c|c|c|}
\hline Citation & Summary of Existing Guidance & Identified Change \\
\hline $\begin{array}{l}\text { NUREG-0800 } \\
6.5 .3 .2\end{array}$ & $\begin{array}{l}\text { The SRP describes the review requirements } \\
\text { for the fission product control systems and } \\
\text { structures, including secondary } \\
\text { containments. }\end{array}$ & $\begin{array}{l}\text { The guidance applies to secondary } \\
\text { containments in Dual Containment systems. } \\
\text { Although the HTGR is not expected to have an } \\
\text { LWR-containment structure, the Reactor } \\
\text { Building is part of the "functional containment" } \\
\text { multiple containment barrier defense-in-depth } \\
\text { strategy. Further HTGR design information of } \\
\text { fission product transport and retention } \\
\text { mechanisms is needed. }\end{array}$ \\
\hline $\begin{array}{l}\text { NUREG-0800 } \\
6.6 .7\end{array}$ & $\begin{array}{l}\text { The SRP describes review requirements for } \\
\text { the augmented ISI program for high-energy } \\
\text { fluid system piping between containment } \\
\text { isolation valves. }\end{array}$ & $\begin{array}{l}\text { This guidance evaluates ISI to protect against } \\
\text { postulated pipe failures. More design } \\
\text { information on HTGR reactor building } \\
\text { isolation is needed to ascertain exactly how this } \\
\text { guidance should be amended or used. }\end{array}$ \\
\hline $\begin{array}{l}\text { NUREG-0800 } \\
\text { BTP 6-3.1, } \\
\text { BTP 6-3.2, } \\
\text { BTP 6-3.3, } \\
\text { BTP 6-3.4, } \\
\text { BTP 6-3.5, } \\
\text { BTP 6-3.6, } \\
\text { BTP 6-3.7, } \\
\text { ВTP 6-3.8, } \\
\text { BTP 6-3.9 }\end{array}$ & $\begin{array}{l}\text { This BTP provides guidance in determining } \\
\text { that portion of the primary containment } \\
\text { leakage not collected and processed by the } \\
\text { secondary containment. Bypass leakage is } \\
\text { defined as leakage from primary } \\
\text { containment which can circumvent the } \\
\text { secondary containment boundary and } \\
\text { escape directly to the environment. }\end{array}$ & $\begin{array}{l}\text { The concept of bypass leakage may apply to } \\
\text { the outer barriers of HTGR functional } \\
\text { containment. Further design detail is needed to } \\
\text { determine if bypass leakage can occur and to } \\
\text { determine how to apply or adapt the BTP } \\
\text { guidance on this topic (if required). }\end{array}$ \\
\hline $\begin{array}{l}\text { NUREG-0800 } \\
\text { BTP 6-4.5 }\end{array}$ & $\begin{array}{l}\text { This BTP pertains to system lines which can } \\
\text { provide open paths from the containment to } \\
\text { the environs during normal plant operation } \\
\text { (e.g., lines of the containment purge and } \\
\text { vent systems). }\end{array}$ & $\begin{array}{l}\text { The HTGR design does not require a similar } \\
\text { primary containment with containment } \\
\text { structure isolation valves. However, some } \\
\text { principles listed in this portion of the BTP } \\
\text { might be applied to the HTGR "functional } \\
\text { containment" system and help determine } \\
\text { appropriate technical specifications and safety } \\
\text { cases. Further design details will be necessary } \\
\text { in order to develop additional guidance. }\end{array}$ \\
\hline $\begin{array}{l}\text { NUREG-0800 } \\
8.3 .1 .7 \\
8.3 .2 .10\end{array}$ & $\begin{array}{l}\text { This section of the SRP provides guidance } \\
\text { on review of DC electrical system } \\
\text { penetrations. }\end{array}$ & $\begin{array}{l}\text { It is not anticipated that the HTGR will require } \\
\text { the type of hardware as described. However, } \\
\text { some type of electrical penetration may be } \\
\text { required. Guidance will be necessary for proper } \\
\text { electrical penetration review once performance } \\
\text { needs are determined by further design. }\end{array}$ \\
\hline $\begin{array}{l}\text { NUREG-0800 } \\
11.1 .1\end{array}$ & $\begin{array}{l}\text { This section of the SRP references } \\
\text { radioactive source terms that must be } \\
\text { considered. }\end{array}$ & $\begin{array}{l}\text { The potential sources of radioactive effluents } \\
\text { listed in Section I of SRP Chap } 11 \text { are specific } \\
\text { to LWRs. An equivalent list needs to be } \\
\text { established for HTGRs. }\end{array}$ \\
\hline
\end{tabular}




\begin{tabular}{|c|c|c|}
\hline Citation & Summary of Existing Guidance & Identified Change \\
\hline $\begin{array}{l}\text { NUREG-0800 } \\
11.1 .2\end{array}$ & $\begin{array}{l}\text { This section of the SRP deals with } \\
\text { radiological effluents and references } \\
\text { NUREG-0016 and NUREG-0017, both of } \\
\text { which are LWR-specific. }\end{array}$ & $\begin{array}{l}\text { The sources listed in Subsection I and in } \\
\text { NUREG-0016 and NUREG-0017 relate only to } \\
\text { PWRs and BWRs. The intent of this guidance } \\
\text { is applicable to HTGRs in that sources of } \\
\text { radioactive effluents should be delineated. } \\
\text { Depending on details of final design, guidance } \\
\text { and code equivalent to NUREG-0016 and } \\
\text { NUREG-0017 may be needed for HTGRs. See } \\
\text { comments in RG } 1.112 \text {. }\end{array}$ \\
\hline $\begin{array}{l}\text { NUREG-0800 } \\
11.1 .4\end{array}$ & $\begin{array}{l}\text { This SRP section references } \\
\text { decontamination factors in NUREG-0016 } \\
\text { and-0017, both of which are LWR-specific. }\end{array}$ & $\begin{array}{l}\text { Decontamination factors equivalent to those } \\
\text { given in NUREG- } 0016 \text { and }-0017 \text { are needed } \\
\text { for HTGRs once the relevant design aspects } \\
\text { become known. See related comment in RG- } \\
1.112 \text {. }\end{array}$ \\
\hline $\begin{array}{l}\text { NUREG-0800 } \\
11.1 .8\end{array}$ & $\begin{array}{l}\text { This section of the SRP references both RG- } \\
1.112 \text { and NUREG- } 0016 \text { and }-0017 \text { for } \\
\text { evaluating source terms, both of which are } \\
\text { LWR-specific. }\end{array}$ & $\begin{array}{l}\text { Information equivalent to that provided in } \\
\text { NUREG-0016 and - } 0017 \text { should be developed } \\
\text { as was recommended in comments to RG- } \\
1.112 \text {, SRP } 11.1 .2 \text { and SRP 11.1.4. }\end{array}$ \\
\hline $\begin{array}{l}\text { NUREG-0800 } \\
\text { BTP 11-5.1 }\end{array}$ & $\begin{array}{l}\text { This BTP provides guidelines on postulated } \\
\text { radioactive releases from a radioactive } \\
\text { waste gas system leak or failure associated } \\
\text { with normal operation and anticipated } \\
\text { operational occurrences. Part B references } \\
\text { LWR-specific codes NUREG-0016 and - } \\
\text { 0017. }\end{array}$ & $\begin{array}{l}\text { Calculation methods for source terms that are } \\
\text { equivalent to those provided in NUREG- } 0016 \\
\text { and }-0017 \text { would need to be developed for } \\
\text { HTGRs as recommended in comments to RG- } \\
\text { 1.112, SRP } 11.1 .2 \text { and SRP 11.1.4. }\end{array}$ \\
\hline $\begin{array}{l}\text { NUREG-0800 } \\
\text { BTP 11-6.2 }\end{array}$ & $\begin{array}{l}\text { This BTP provides guidelines defining the } \\
\text { mechanism of the failure of the liquid waste } \\
\text { management system, assumptions used for } \\
\text { the analysis, and an approach applied in } \\
\text { assessing the radiological impact. } \\
\text { Recommendations for source term } \\
\text { calculation assume an LWR. }\end{array}$ & $\begin{array}{l}\text { Additional details are required in order that } \\
\text { radionuclide concentrations and total inventory } \\
\text { of radioactive materials can be calculated for } \\
\text { HTGRs. }{ }^{1}\end{array}$ \\
\hline $\begin{array}{l}\text { NUREG-0800 } \\
13.3 .5\end{array}$ & $\begin{array}{l}\text { This SRP section addresses clarifications in } \\
\text { emergency planning as described in the } \\
\text { Safety Analysis Report. }\end{array}$ & $\begin{array}{l}\text { This item applies to LWRs and should be } \\
\text { reviewed and adapted as necessary for HTGRs. } \\
\text { An NGNP licensing white paper has been } \\
\text { developed covering this topic. }\end{array}$ \\
\hline $\begin{array}{l}\text { NUREG-0800 } \\
13.3 .12\end{array}$ & $\begin{array}{l}\text { This SRP section addresses an emergency } \\
\text { response data system for emergency } \\
\text { planning, as described in the Safety } \\
\text { Analysis Report. }\end{array}$ & $\begin{array}{l}\text { Appendix E to } 10 \text { CFR } 50 \text { specifies } \\
\text { requirements for BWRs and PWRs. Equivalent } \\
\text { requirements remain to be developed for } \\
\text { HTGRs. Guidance provided in NUREG } 1394 \\
\text { should be adapted for HTGRs. }{ }^{2}\end{array}$ \\
\hline $\begin{array}{l}\text { NUREG-0800 } \\
13.3 .17\end{array}$ & $\begin{array}{l}\text { This SRP section addresses emergency } \\
\text { planning as described in the Safety Analysis } \\
\text { Report. }\end{array}$ & $\begin{array}{l}\text { The } 10 \text { mile emergency planning zone should } \\
\text { be revised to reflect HTGR criteria. }{ }^{2}\end{array}$ \\
\hline $\begin{array}{l}\text { NUREG-0800 } \\
13.5 .2 .1 .2\end{array}$ & $\begin{array}{l}\text { This SRP section addresses the review of } \\
\text { the plan for development and } \\
\text { implementation of operating procedures as } \\
\text { described in the Safety Analysis Report. }\end{array}$ & $\begin{array}{l}\text { Parts D (NUREG-0737) \& F (RG-1.33) of the } \\
\text { SRP criteria set several requirements which are } \\
\text { specific to PWRs and BWRS. These } \\
\text { requirements should be adapted to HTGRs } \\
\text { either by supplement to those documents or as } \\
\text { revised guidance in this SRP section. }\end{array}$ \\
\hline
\end{tabular}




\begin{tabular}{|c|c|c|}
\hline Citation & Summary of Existing Guidance & Identified Change \\
\hline $\begin{array}{l}\text { NUREG-0800 } \\
15.2 .6 .5\end{array}$ & $\begin{array}{l}\text { This SRP section addresses review of the } \\
\text { plan for loss of nonemergency AC power } \\
\text { which is assumed to result in the loss of all } \\
\text { power to the station auxiliaries. }\end{array}$ & $\begin{array}{l}\text { Guidance for PWR and BWR scram } \\
\text { characteristics is provided but not for a HTGR. } \\
\text { Further design details will be needed to enable } \\
\text { paragraph B to be adapted to include HTGR } \\
\text { requirements for a scram. }\end{array}$ \\
\hline $\begin{array}{l}\text { NUREG-0800 } \\
15.3 .1 .9\end{array}$ & $\begin{array}{l}\text { This SRP section addresses the review of } \\
\text { the plan for loss of reactor coolant flow. }\end{array}$ & $\begin{array}{l}\text { Guidance for PWR and BWR scram } \\
\text { characteristics is provided but not for an } \\
\text { HTGR. The scram characteristics of an HTGR } \\
\text { should be appended to paragraph B. }\end{array}$ \\
\hline $\begin{array}{l}\text { NUREG-0800 } \\
15.3 .3\end{array}$ & $\begin{array}{l}\text { This SRP section addresses the review of } \\
\text { events postulated as a result of an } \\
\text { instantaneous seizure of the rotor or break } \\
\text { of the shaft of a reactor coolant pump in a } \\
\text { PWR or recirculation pump in a BWR. }\end{array}$ & $\begin{array}{l}\text { Paragraphs } 4,6 \text { and } 7 \text { of the SRP should be } \\
\text { adapted to accommodate HTGRs as supporting } \\
\text { design details become available. HTGRs do not } \\
\text { have reactor coolant pumps but primary coolant } \\
\text { blowers/ circulators are present. }\end{array}$ \\
\hline $\begin{array}{l}\text { NUREG-0800 } \\
16.1 .2\end{array}$ & $\begin{array}{l}\text { This SRP addresses application of } \\
\text { Probabilistic Risk Assessment (PRA) to } \\
\text { evaluate changes in a technical } \\
\text { specification. The SRP references RG-1.174 } \\
\text { for specific direction. }\end{array}$ & $\begin{array}{l}\text { RG-1.174 must be adapted. Alternative metrics } \\
\text { to CDF and LERF should be developed in } \\
\text { order to make this RG relevant for HTGRs. See } \\
\text { comment in RG-1.174. An alternative set of } \\
\text { risk metrics has been provided in an NGNP } \\
\text { licensing white paper. }\end{array}$ \\
\hline $\begin{array}{l}\text { NUREG-1555 } \\
3.2\end{array}$ & $\begin{array}{l}\text { The third stated position requires that the } \\
\text { Environmental Report (ER) must comply } \\
\text { with the requirements of } 10 \text { CFR } 51.52 \text { with } \\
\text { respect to the environmental effects that } \\
\text { arise from the transportation of fuel and } \\
\text { waste from the facility. }\end{array}$ & $\begin{array}{l}\text { The SRP references } 10 \text { CFR } 51.52 \text { Table S- } 4 \text {. } \\
\text { Table S- } 4 \text { should be evaluated and adapted for } \\
\text { applicability to HTGR fuel and waste } \\
\text { transportation when that information becomes } \\
\text { available through design. See comment in } \\
\S 51.52 \text {. }\end{array}$ \\
\hline $\begin{array}{l}\text { NUREG-1555 } \\
5.7 .1\end{array}$ & $\begin{array}{l}\text { The SRP requires that the ER must address } \\
\text { the impacts on the uranium fuel cycle based } \\
\text { on a non-LWR design. Reference is made to } \\
\text { Table } S-3 \text { in } \S 51.51 \text {. }\end{array}$ & $\begin{array}{l}\text { Table S-3 should be evaluated and updated for } \\
\text { its applicability to the HTGR fuel cycle. } \\
\text { Additional design information will be needed } \\
\text { to address this issue. }\end{array}$ \\
\hline $\begin{array}{l}\text { NUREG-1555 } \\
05.7 .2\end{array}$ & $\begin{array}{l}\text { The SRP requires that the ER must comply } \\
\text { with the requirements of } 10 \text { CFR } 51.52 \text { with } \\
\text { respect to the environmental effects that } \\
\text { arise from the transportation of fuel and } \\
\text { waste from the facility. }\end{array}$ & $\begin{array}{l}\text { The SRP references } 10 \text { CFR } 51.52 \text { Table S- } 4 \text {. } \\
\text { Table S- } 4 \text { should be evaluated and adapted for } \\
\text { its applicability to HTGR fuel and waste } \\
\text { transportation when that information becomes } \\
\text { available through design. See comment in } \\
\S 51.52 \text {. }\end{array}$ \\
\hline $\begin{array}{l}\text { NUREG-1555 } \\
5.9\end{array}$ & $\begin{array}{l}\text { This SRP addresses reporting requirements } \\
\text { for decommissioning that must be presented } \\
\text { in the ER. }\end{array}$ & $\begin{array}{l}10 \text { CFR } 50.75 \text { needs to be clarified to include } \\
\text { HTGRs. See comment in } \S 50.75 \text {. }\end{array}$ \\
\hline DC/COL-ISG-3 & $\begin{array}{l}\text { Interim Staff Guidance (ISG) addresses } \\
\text { what PRA information is needed to support } \\
\text { design certification and combined license } \\
\text { (COL) applications. }\end{array}$ & $\begin{array}{l}\text { The ISG references CDF and LRF, which are } \\
\text { not appropriate HTGR Risk metrics. } \\
\text { Alternative metrics need to be developed, as } \\
\text { proposed in the associated NGNP licensing } \\
\text { white paper. }\end{array}$ \\
\hline DC/COL-ISG-5 & $\begin{array}{l}\text { ISG addresses the use of GALE } 86 \text { Code for } \\
\text { calculation of routine radioactive releases in } \\
\text { gaseous and liquid effluents to support DCs } \\
\text { and COL applications. }\end{array}$ & $\begin{array}{l}\text { Clarification of ISG is necessary regarding the } \\
\text { applicability of GALE } 86 \text { to HTGRs. Additional } \\
\text { design information is needed to support this } \\
\text { work. }\end{array}$ \\
\hline
\end{tabular}




\begin{tabular}{|c|c|c|}
\hline Citation & Summary of Existing Guidance & Identified Change \\
\hline DC/COL-ISG-013 & $\begin{array}{l}\text { ISG addresses NUREG- } 0800 \text { SRP Section } \\
11.2 \text { and Branch Technical Position } 11-6 \\
\text { concerning assessing the consequences of } \\
\text { an accidental release of radioactive } \\
\text { materials from liquid waste tanks for COL } \\
\text { applications. }\end{array}$ & $\begin{array}{l}\text { Contingent upon details of final design, Table } 1 \\
\text { source term radionuclides may need adjustment } \\
\text { to address HTGRs. }\end{array}$ \\
\hline DI\&C-ISG-003 & $\begin{array}{l}\text { ISG addresses how to conduct a review of } \\
\text { new reactor digital instrumentation and } \\
\text { control PRA. }\end{array}$ & $\begin{array}{l}\text { Alternatives to the risk metrics referenced in } \\
\text { the ISG (CDF and LERF) must be developed } \\
\text { for HTGRs. An approach to this issue is } \\
\text { contained in a NGNP white paper on Licensing } \\
\text { Basis Event selection. }\end{array}$ \\
\hline NSIR/DPR-ISG-01 & $\begin{array}{l}\text { The ISG cites NRC emergency planning } \\
\text { regulations and guidance which are based } \\
\text { primarily on LWR technology. }\end{array}$ & $\begin{array}{l}\text { ISG should be amended to address the } \\
\text { significantly reduced public risk that } \\
\text { accompanies the HTGR design. Planning } \\
\text { standards such as organization and staffing, } \\
\text { facilities, emergency classification, assessment, } \\
\text { prompt notification, onsite and offsite response, } \\
\text { training, and periodic drills and exercises will } \\
\text { need to be addressed in a manner consistent } \\
\text { with the design and operating characteristics of } \\
\text { the HTGR. }\end{array}$ \\
\hline $\begin{array}{l}\text { NUREG-0737 } \\
\text { II.F. } 2[10 \text { CFR } 50.34 \\
\text { (f)(2)(xviii)] }\end{array}$ & $\begin{array}{l}\text { TMI action requiring that control room } \\
\text { instruments provide an unambiguous } \\
\text { indication of inadequate core cooling. }\end{array}$ & $\begin{array}{l}\text { Further design is needed to resolve this item. } \\
\text { The need for in-core instrumentation to monitor } \\
\text { adequate core cooling during an accident } \\
\text { remains to be determined for HTGRs. } \\
\text { Measurement of core cooling via other means } \\
\text { may be an option. }\end{array}$ \\
\hline $\begin{array}{l}\text { NUREG-0737 } \\
\text { II.F. } 3[10 \text { CFR } 50.34 \\
\text { (f)(2)(xix)] }\end{array}$ & $\begin{array}{l}\text { TMI action requiring that control room } \\
\text { instruments provide adequate monitoring of } \\
\text { plant conditions following an accident that } \\
\text { includes core damage. }\end{array}$ & $\begin{array}{l}\text { Instrumentation to monitor adequate plant } \\
\text { conditions following an accident may need to } \\
\text { be identified for HTGRs. }\end{array}$ \\
\hline
\end{tabular}

\section{References}

1 INL/EXT-10-17997, “Mechanistic Source Terms White Paper,” Revision 0, July 2010.

2 INL/MIS-10-19799, "Determining the Appropriate Emergency Planning Zone Size and Emergency Planning Attributes for an HTGR,” Revision 0, October 2010.

3 INL/EXT-10-19521, "Next Generation Nuclear Plant Licensing Basis Event Selection White Paper," September 2010

4 DOE-HTGR-86-024, "Preliminary Safety Information Document for the Standard MHTGR," Amendment 13, August 7, 1992. 
Appendix B

\section{Summary Table of Additional Design Information Needed}




\section{Appendix B \\ Summary Table of Additional Design Information Needed}

The 14 issues listed below were items for which HTGR licensing applicability could not be determined due to a lack of supporting design information. Depending on future decisions, these items may or may not apply to the HTGR licensing framework. Resolution to these issues is directly contingent upon the availability of specific HTGR design details that are typically contained in a COL application.

Table B-1. Additional Design Information Needed.

\begin{tabular}{|c|c|c|}
\hline Citation & Current Information & Additional Design Information \\
\hline 50, App J & $\begin{array}{l}\text { App J provides details on requirements for } \\
\text { leak detection within LWR containment } \\
\text { structures. }\end{array}$ & $\begin{array}{l}\text { Paragraph (IV.B) provides for setting up } \\
\text { periodic testing to meet technical } \\
\text { specifications for required building leak } \\
\text { tightness. Additional design information } \\
\text { concerning reactor building overall leak } \\
\text { tightness, vent path configuration, filtration } \\
\text { requirements, and requirements for } \\
\text { compartmentalization is needed to determine } \\
\text { whether paragraph (IV.B) applies to HTGRs. }\end{array}$ \\
\hline RG-1.13.C.4 & $\begin{array}{l}\text { This RG section addresses need for a } \\
\text { controlled leakage building for spent fuel } \\
\text { storage. }\end{array}$ & $\begin{array}{l}\text { Applicability will depend on detailed design } \\
\text { and safety case. If filters are not safety related } \\
\text { then RG-1.140 would apply. }\end{array}$ \\
\hline $\begin{array}{l}\text { RG-1.54,1 } \\
\text { RG-1.54,2 } \\
\text { RG-1.54,4 }\end{array}$ & $\begin{array}{l}\text { This RG describes a method for the selection, } \\
\text { application, qualification, inspection, and } \\
\text { maintenance of protective coatings applied to } \\
\text { nuclear power plants. }\end{array}$ & $\begin{array}{l}\text { The placement and function of protective } \\
\text { coatings with respect to HTGR safety systems } \\
\text { is not yet understood and may deviate from } \\
\text { those established for LWRs. The applicability } \\
\text { of this guidance will be determined based on } \\
\text { final design information. }\end{array}$ \\
\hline RG-1.128 & $\begin{array}{l}\text { This } R G \text { addresses installation of, and } \\
\text { requirements for, lead-acid batteries. }\end{array}$ & $\begin{array}{l}\text { This RG was assumed to be applicable to } \\
\text { HTGR licensing. Additional design } \\
\text { information is needed to confirm applicable } \\
\text { requirements for lead-acid storage batteries. }\end{array}$ \\
\hline RG-1.129 & $\begin{array}{l}\text { This RG addresses maintenance and testing } \\
\text { of lead-acid batteries. }\end{array}$ & $\begin{array}{l}\text { This RG was assumed to be applicable. } \\
\text { Additional design information is needed to } \\
\text { confirm applicable requirements for lead-acid } \\
\text { storage batteries. }\end{array}$ \\
\hline RG-1.158 & $\begin{array}{l}\text { This } R G \text { addresses the qualification of } \\
\text { safety-related lead-acid batteries. }\end{array}$ & $\begin{array}{l}\text { Design information is needed to assess } \\
\text { applicable requirements for lead-acid storage } \\
\text { batteries. }\end{array}$ \\
\hline RG-4.1.C.7 & $\begin{array}{l}\text { This RG describes a method the NRC } \\
\text { considers acceptable for use in establishing } \\
\text { and conducting an environmental monitoring } \\
\text { program at nuclear power plants. }\end{array}$ & $\begin{array}{l}\text { With respect to paragraph }(\mathrm{d}) \text {, additional } \\
\text { design data is necessary to verify whether C- } \\
14 \text { emissions from an HTGR are comparable } \\
\text { to that of a LWR. }\end{array}$ \\
\hline
\end{tabular}




\begin{tabular}{|l|l|l|}
\hline \multicolumn{1}{|c|}{ Citation } & \multicolumn{1}{|c|}{ Current Information } & \multicolumn{1}{c|}{ Additional Design Information } \\
\hline $\begin{array}{l}\text { NUREG-0800 } \\
\text { 6.1.2.1 }\end{array}$ & $\begin{array}{l}\text { This addresses acceptance of coating systems } \\
\text { inside containment. }\end{array}$ & $\begin{array}{l}\text { The placement and function of protective } \\
\text { coatings with respect to the operation of } \\
\text { HTGR safety systems is not yet understood } \\
\text { and may differ from those established for light } \\
\text { water reactors. Issue is related to RG-1.54 and } \\
\text { will be determined based on parameters of } \\
\text { final HTGR design. }\end{array}$ \\
\hline $\begin{array}{l}\text { NUREG-0800 } \\
9.3 .1 .2\end{array}$ & $\begin{array}{l}\text { This establishes criteria for review of } \\
\text { compressed air systems. }\end{array}$ & $\begin{array}{l}\text { The MHTGR-PSID } \text { classifies the instrument } \\
\text { and service air system as non-safety related. } \\
\text { Additional design information is needed to } \\
\text { determine if any portion of the air system is } \\
\text { designated as safety-related. }\end{array}$ \\
\hline $\begin{array}{l}\text { NUREG-0800 } \\
9.3 .1 .4\end{array}$ & $\begin{array}{l}\text { This establishes criteria for review of } \\
\text { compressed air systems. }\end{array}$ & $\begin{array}{l}\text { The MHTGR-PSID } \text { classifies the instrument } \\
\text { and service air system as non-safety related. } \\
\text { This section might become applicable if } \\
\text { additional design information determines that } \\
\text { any portion of the air system is required to } \\
\text { accommodate a station blackout. }\end{array}$ \\
\hline $\begin{array}{l}\text { NUREG-0737 } \\
\text { II.D.1[10CFR50.34 } \\
\text { (f)(2)(x)] }\end{array}$ & $\begin{array}{l}\text { TMI requirement on test program for reactor } \\
\text { pressure boundary relief and safety valves }\end{array}$ & $\begin{array}{l}\text { HTGR will have relief valves in the helium } \\
\text { pressure boundary. It is not known if these } \\
\text { will be safety related. }\end{array}$ \\
\hline $\begin{array}{l}\text { NUREG-0737 } \\
\text { II.D.3[10CFR50.34 } \\
\text { (f)(2)(xi)] }\end{array}$ & $\begin{array}{l}\text { TMI requirement on instrumentation in } \\
\text { control room for reactor pressure boundary } \\
\text { relief and safety valves. }\end{array}$ & $\begin{array}{l}\text { HTGR will have relief valves in the helium } \\
\text { pressure boundary. It is not known if these } \\
\text { will be safety related. }\end{array}$ \\
\hline
\end{tabular}

\section{References}

1 DOE-HTGR-86-024,"Preliminary Safety Information Document for the Standard MHTGR," Amendment 13, August 7, 1992. 


\section{Appendix C}

\section{Table of Key Regulatory Guidance To Be Developed}




\section{Appendix C \\ Table of Key Regulatory Guidance To Be Developed}

A series of key topics were identified that will require development of new regulatory guidance in order to provide for the licensing of modular HTGRs. These issues are not fully addressed in the regulations or guidance documents that were evaluated during the RGA. This is due to the specific and basic differences in key aspects of HTGR design and event response when compared to LWR design and the overall content of the predominantly LWR-based structure of existing regulatory guidance. Because they are considered significant, it is recommended that these topics be further evaluated and addressed to provide a more comprehensive HTGR licensing framework. It is noted that many of these issues have been previously addressed through NGNP licensing white papers, as referenced in the table below.

Table C-1. HTGR Regulatory Guidance to be Developed

\begin{tabular}{|c|c|}
\hline HTGR Regulatory Topic & Remarks \\
\hline HTGR Fuel, Design and Qualification & $\begin{array}{l}\text { Requirements associated with fuel qualification are generally and } \\
\text { fundamentally applicable to HTGRs. The specific goals for HTGR fuel } \\
\text { qualification are unique in that the fuel coating system is relied upon to } \\
\text { contain fission products at very high temperatures. An approach for } \\
\text { applying regulations and guidance for HTGRs is addressed in the } \\
\text { "NGNP Fuel Qualification White Paper."1 }\end{array}$ \\
\hline $\begin{array}{l}\text { High-Temperature Ceramic Materials (e.g. } \\
\text { Graphite), Composites, Reactor Internal } \\
\text { Structures and Components Design, } \\
\text { Manufacturing, Inspection, and Testing }\end{array}$ & $\begin{array}{l}\text { Current regulations and guidance are oriented to the use of metallic } \\
\text { core internals as well as pressure vessels. The ASME code has } \\
\text { provision for qualifying alternative metallic materials for high } \\
\text { temperature applications. ASME III does not cover the non-metallic } \\
\text { materials utilized in combination with metallic materials as is done in } \\
\text { HTGRs. }\end{array}$ \\
\hline $\begin{array}{l}\text { "Functional Containment" of Radionuclide } \\
\text { Releases }\end{array}$ & $\begin{array}{l}\text { The modular HTGR context employs "functional containment" insofar } \\
\text { as it offers multiple barriers to fission product release and radionuclide } \\
\text { transport functions. This limits the release of radionuclides to the } \\
\text { environment. The concept of functional containment performance is } \\
\text { not clearly acknowledged in existing regulations nor does existing } \\
\text { guidance on how to meet those requirements communicate appropriate } \\
\text { acceptance criteria as is the case with the "essentially leak tight" } \\
\text { performance expectations of LWRs. }\end{array}$ \\
\hline Risk Metrics & $\begin{array}{l}\text { Use of PRAs for LWRs is based on definitions of the reactor plant } \\
\text { state of core damage such as liquid coolant levels in the reactor vessel, } \\
\text { coolant outlet temperatures indicative of inadequate core cooling, and } \\
\text { achievement of core temperatures at which damage to the Zircaloy } \\
\text { clad fuel elements and fuel melting are expected to occur. It has been } \\
\text { determined that CDF and LERF measures in LWRs are inappropriate } \\
\text { risk metrics for HTGRs. Alternative risk metrics must be established } \\
\text { as PRAs are being developed to support design and licensing of } \\
\text { HTGRs. An approach to this issue is presented in a NGNP white paper } \\
\text { on Licensing Basis Event selection. }\end{array}$ \\
\hline
\end{tabular}




\begin{tabular}{|l|l|}
\hline HTGR Regulatory Topic & Remarks \\
\hline Passive Safety in HTGRs & $\begin{array}{l}\text { The HTGR utilizes a safety-related passive heat removal system } \\
\text { through appropriate design of a vessel system and reactor cavity } \\
\text { cooling system. These systems, coupled with the fuel's resistance to } \\
\text { damage at high temperature, provide the mechanism for emergency } \\
\text { core cooling that functionality is addressed in 10 CFR Part 50.46, } \\
\text { GDC 34, and SRP Chapter 6. However, there is virtually no specific } \\
\text { guidance available concerning the expected performance standards and } \\
\text { acceptance criteria for HTGR passive safety features. }\end{array}$ \\
\hline Helium Leak and Leak Detection & $\begin{array}{l}\text { High temperature helium leaks have certain safety implications like } \\
\text { those related to jet impingement, fire, operator safety, etc. The } \\
\text { consequences of helium coolant primary fluid leak are completely } \\
\text { different than those of a LWR. Systematic approaches to address these } \\
\text { consequences should be further considered. }\end{array}$ \\
\hline Safety Classification for HTGRs & $\begin{array}{l}\text { Functional safety classification is normally related to plant states under } \\
\text { varying plant conditions. It is important to classify the safety } \\
\text { significance level and the associated quality, structural, seismic, } \\
\text { control, and testing classes at each of the various conditions. While } \\
\text { these actions are well established for LWRs, they will be quite } \\
\text { different for HTGRs. Establishing authoritative guidance on the proper } \\
\text { treatment of HTGR safety-related systems is important to HTGR } \\
\text { licensing. An approach to safety classifications is provided in a NGNP } \\
\text { white paper. }\end{array}$ \\
\hline HTGR Accident Analysis Guide & $\begin{array}{l}\text { Because the types of events, their classification, thermo-hydraulic } \\
\text { transients, product behavior, mitigation, control functions, defense in } \\
\text { depth and fission product barriers for HTGRs are different from } \\
\text { LWRs, unique guides to HTGR accident analysis must be developed. } \\
\text { Severe accidents and acceptance limits should form a part of this } \\
\text { guide/regulation. NGNP has developed white papers on this topic. }\end{array}$ \\
\hline 5,7
\end{tabular}

\section{References}

1 INL/EXT-10-18610, “NGNP Fuel Qualification White Paper,” Revision 0, July 2010.

2 INL/EXT-09-17187, “NGNP High Temperature Material White Paper,” June 2010.

3 INL/EXT-06-11701, "Next Generation Nuclear Plant Materials Research and Development Plan," Revision 4, October 3, 2007.

4 INL/EXT-10-17997, “Mechanistic Source Terms White Paper,” Revision 0, July 2010.

5 INL/EXT-10-19521, "Next Generation Nuclear Plant Licensing Basis Event Selection White Paper," September 2010.

6 INL/EXT-10-19509, "Next Generation Nuclear Plant Structures, Systems, and Components Safety Classification White Paper," September 2010

7 INL/EXT-09-17139, "Next Generation Nuclear Plant Defense-in-Depth Approach,” December 2009. 